\title{
Future perspectives of selective estrogen receptor modulators used alone and in combination with DHEA
}

\author{
F Labrie
}

Molecular Endocrinology and Oncology Research Center, Laval University Hospital Research Center (CRCHUL) and Laval University, 2705, Laurier Boulevard, Quebec City, Quebec G1V 4G2, Canada

(Requests for offprints should be addressed to F Labrie; Email: fernand.labrie @ crchul.ulaval.ca)

\begin{abstract}
Breast cancer is the most frequently diagnosed and the second cause of cancer death in women, thus making breast cancer a most feared disease. Since breast cancer metastasizes early and it is unlikely that improvements in the treatment of metastatic disease could permit a cure in most cases in the foreseeable future, it is clear that prevention is essential in order practically to eliminate deaths from breast cancer. Tamoxifen is the only selective estrogen receptor modulator (SERM) currently registered for use in breast cancer prevention; the tamoxifen versus raloxifene study should indicate the efficacy of this compound compared with raloxifene. The recent benefits of aromatase inhibitors over tamoxifen indicate the advantages of a blockade of estrogens more complete than the one achieved with tamoxifen, a SERM having some estrogenic activity in the mammary gland and an even higher estrogenic action in the uterus. However, it is unlikely that the general estrogen ablation achieved with aromatase inhibitors will be acceptable for the long-term use required for prevention. It is thus important to develop SERMs with highly potent and pure antagonistic activity in the mammary gland and uterus while possessing estrogen-like activity in tissues of particular importance for women's health, namely the bones and the cardiovascular system. However, it is expected that a SERM alone will not meet all the requirements of women's health at the postmenopause when ovarian estrogen secretion has ceased and peripheral formation of androgens and estrogens from DHEA by intracrine mechanisms is decreased by $60 \%$ or more. One possibility is to combine a SERM with DHEA, a precursor of sex steroids that permits, somewhat like SERMs, tissue-specific formation of androgens and/or estrogens according to the level of expression of the steroidogenic and steroid-inactivating enzymes. DHEA could thus compensate for the important loss of androgens that accompanies aging and could also permit sex steroid formation and action in the brain while breast cancer prevention would be achieved by the SERM.
\end{abstract}

Endocrine-Related Cancer (2006) 13 335-355

\section{Introduction}

Breast cancer is diagnosed in more than 1 million women worldwide yearly. Since it is unlikely that improvements in the treatment of advanced breast cancer will permit the cure of most cases in the foreseeable future, and breast cancer has already metastasized in $50-60 \%$ of cases at the time of diagnosis, the development of an efficient and welltolerated prevention strategy is imperative. Tamoxifen has provided proof-of-principle data showing that a selective estrogen receptor modulator
(SERM) is efficacious in both the treatment and the prevention of breast cancer (Fisher et al. 1998).

According to the latest Oxford analysis of the Early Breast Cancer Triallist's Collaborative Group (EBCTCG; 2005), 5 years of tamoxifen treatment in the adjuvant setting produced, after 15 years of follow-up, an $11.8 \pm 1.3 \%$ absolute reduction in breast cancer recurrence and a $9.2 \pm 1.2 \%$ reduction in breast cancer mortality in women with estrogen receptor (ER)-positive tumors. Treatment with the SERM raloxifene caused a dramatic $76 \%$ decrease in breast cancer incidence following 3 years of its 
administration in osteoporotic postmenopausal women (Cummings et al. 1999). For the remaining $24 \%$, it is possible that they represent cancers which had already developed alternative pathways of survival because of an advanced stage. The study of tamoxifen versus raloxifene (STAR trial) should define the relative merits of tamoxifen and raloxifene in preventing breast cancer in the adjuvant setting.

Long-term treatment with tamoxifen, however, is well known to have side-effects related to the partial agonistic activity of this compound, especially the increased risk of endometrial cancer and thromboembolic events (Fisher et al. 1994, Jaiyesimi et al. 1995, EBCTCG 2005). Moreover, tamoxifen therapy over 5 years does not seem to convey additional benefits and may even bring negative effects (Fisher et al. 1996, 2001, Peto 1996). In addition, resistance to tamoxifen is a well-established phenomenon (Clarke et al. 2001). The limit of 5 years of tamoxifen administration and its estrogenic side-effects indicate the need to search for improved SERMs.

The ATAC study of anastrazole and tamoxifen alone or in combination study (Baum et al. 2003) has recently shown the improved efficacy of anastrozole over tamoxifen, thus suggesting the use of 5 years of anastrozole instead of tamoxifen adjuvant therapy for postmenopausal women with early breast cancer (Howell et al. 2005). Moreover, studies with anastrozole, letrozole and exemestane have shown the benefits of switching from tamoxifen to an aromatase inhibitor (Goss et al. 2003, Coombes et al. 2004, Jakesz et al. 2005). It should be mentioned that, despite the relatively short-term duration of the studies performed with aromatase inhibitors, an increased number of fractures have been found with all the aromatase inhibitors compared with tamoxifen (Baum et al. 2002, Coleman et al. 2004, Coombes et al. 2004, Jakesz et al. 2005, Lonning et al. 2005). Moreover, despite the advantages of switching to an aromatase inhibitor, the advantages obtained are still far from the prevention of recurrence in all patients, and resistance to aromatase inhibitors develops (Goss 2002).

In this context of general estrogen deprivation caused by aromatase inhibitors, estrogen deficiency has been reported to have a negative effect on cognitive status, especially short- and long-term memory (Sherwin 2003, Tralongo et al. 2005). Preliminary data have indicated a higher incidence of impaired word finding in women who were treated with the aromatase inhibitor exemestane compared with tamoxifen (Jones et al. 2003). Such data raise questions about the long-term effects of general estrogen deprivation on cognitive function, a problem which could be amplified under the long-term conditions of prevention.

Despite the limitations mentioned above with the presently available drugs, it is well recognized that estrogens play the predominant role in breast cancer development and growth. Therefore, estrogen deprivation should be part of the strategy of prevention. However, as mentioned above, it is unlikely that generalized estrogen deprivation, such as achieved with aromatase inhibitors, will be acceptable for long-term use. It thus seems logical to suggest that SERMs, with their tissue-specific action, are the class of drugs upon which the best hope for an efficient and well-tolerated preventative therapy for breast cancer relies.

One essential characteristic of the SERM(s) chosen for prevention of breast cancer should be that they are compounds free of any agonistic activity in the mammary gland and uterus while exerting estrogen-like activity in other tissues of importance for women's health. It is also possible that the best strategy for global women's health will be a combination of a SERM with a tissue-specific precursor of sex steroids, in order to compensate for the progressive loss of androgens with age, while permitting estrogen formation in the brain in order to protect cognitive function.

\section{Endocrinology of the mammary gland, breast cancer and women's health}

\section{Endocrinology of the normal mammary gland: intracrinology}

It is remarkable that man, in addition to possessing very sophisticated endocrine and paracrine systems, has vested largely in sex steroid formation in peripheral tissues (Labrie 1991, Labrie et al. 1985, 1988, 1997a, Simpson 2000). In fact, while the ovaries and testes are the exclusive sources of androgens and estrogens in lower mammals, the situation is very different in man and higher primates, where active sex steroids are a very large part (androgens) or are wholly (estrogens after the menopause) synthesized locally in peripheral tissues, thus providing target tissues with the appropriate controls which permit adjustment of the formation and metabolism of sex steroids according to local needs (Fig. 1).

The rate of cell-specific transformation of the adrenal precursor steroids DHEA and DHEA sulfate (DHEA-S) into androgens and/or estrogens in each peripheral target tissue thus depends upon 


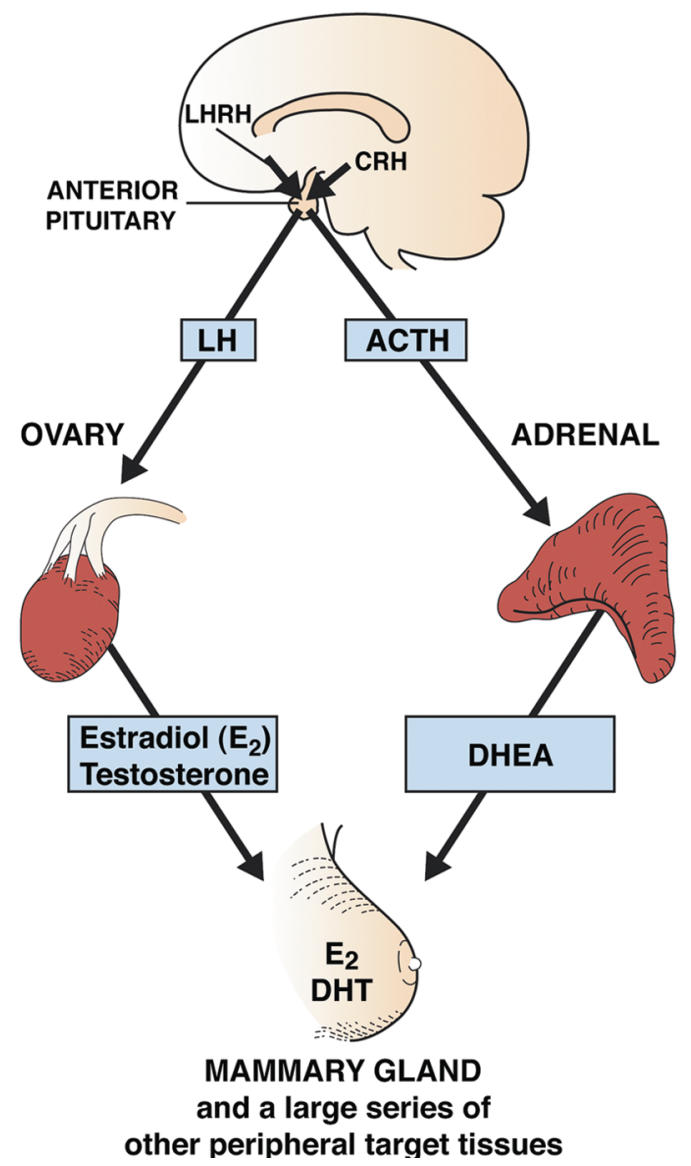

Figure 1 Schematic representation of the role of ovarian and adrenal sources of sex steroids in premenopausal women. After menopause, the secretion of estradiol by the ovaries ceases and then almost $100 \%$ of sex steroids are made locally in peripheral target intracrine tissues. ACTH, adrenocorticotropin; DHEA, dehydroepiandrosterone; $\mathrm{DHT}$, dihydrotestosterone; $\mathrm{E}_{2}$, $17 \beta$-estradiol; LH, luteinizing hormone; LHRH, LH-releasing hormone; $\mathrm{CRH}$, corticotropin-releasing hormone.

the level of expression of the various steroidogenic and metabolizing enzymes in each cell of each tissue (Fig. 2). This sector of endocrinology that focuses on the intracellular hormone formation and action has been called intracrinology (Labrie et al. 1988, Labrie 1991).

In women, the role of the adrenal precursors DHEA and DHEA-S in the peripheral formation of sex steroids is even more important than in men. In fact, in men, androgen secretion by the testes continues at a high level throughout life while, in women, estrogen secretion by the ovaries completely ceases at menopause, thus leaving the adrenals as the primary source of precursors of sex steroids. In fact, the best estimate is that the intracrine formation of estrogens in peripheral tissues in women is $100 \%$ after the menopause while the vast majority of androgens are also made locally from DHEA throughout life (Adams 1985, Labrie et al. 2003a).

In addition to $E_{2}$, another important but still largely unrecognized estrogen is androst-5-ene-

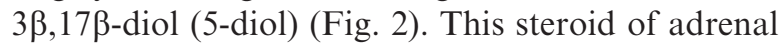
origin has, in fact, been shown to exert direct estrogenic effects in both normal and malignant estrogen-sensitive tissues at concentrations found in the circulation of normal adult women (Adams 1985, Poulin \& Labrie 1986, Simard et al. 1988). It should be emphasized that aromatase inhibitors do not affect the formation of this estrogen, thus leaving 5-diol free to continue to stimulate breast cancer after inhibition of $\mathrm{E}_{2}$ formation. As mentioned earlier, the 100-fold higher concentration of DHEA in the mammary gland versus plasma is accompanied by parallel findings for the estrogenic 5-diol (Poortman et al. 1983).

The major importance of estrogen formation in peripheral tissues after the menopause is also clearly supported by the finding that tissue levels of $\mathrm{E}_{2}$ remain elevated at about $200 \mathrm{pg} / \mathrm{ml}$ in breast cancer tissue after the menopause while plasma levels of $E_{2}$ are decreased below $10 \mathrm{pg} / \mathrm{ml}$ (Poortman et al. 1983). In fact, in breast cancer tissue, it is remarkable that the concentration of $\mathrm{E}_{2}$ is similar in pre- and postmenopausal women (Poortman et al. 1983). The major role of peripheral estrogen formation in postmenopausal women is well demonstrated by the observation of the major benefits of aromatase inhibitors in advanced breast cancer in postmenopausal women (Nabholtz et al. 2000, Goss et al. 2003, Mouridsen et al. 2003) as well as by the findings of a $76 \%$ decrease in breast cancer incidence in postmenopausal osteoporotic women who received the SERM raloxifene for 3 years (Cummings et al. 1999).

The role of DHEA in peripheral tissues is well supported by the observation that the concentration of DHEA in retroperitoneal fat in postmenopausal women is approximately 100 -fold higher than the serum concentration, thus providing a high level of substrate for the local intracellular formation of androgens and/or estrogens (Szymczak et al. 1998). That the high intracellular levels of estrogens after the menopause are not limited to breast cancer is illustrated by the observation that the concentration of $E_{2}$ is about five times higher in retroperitoneal fat than in plasma levels in postmenopausal women (Szymczak et al. 1998). Such data, showing that relatively high levels of $E_{2}$ remain present in peripheral tissues after the menopause, suggest that removal of these 


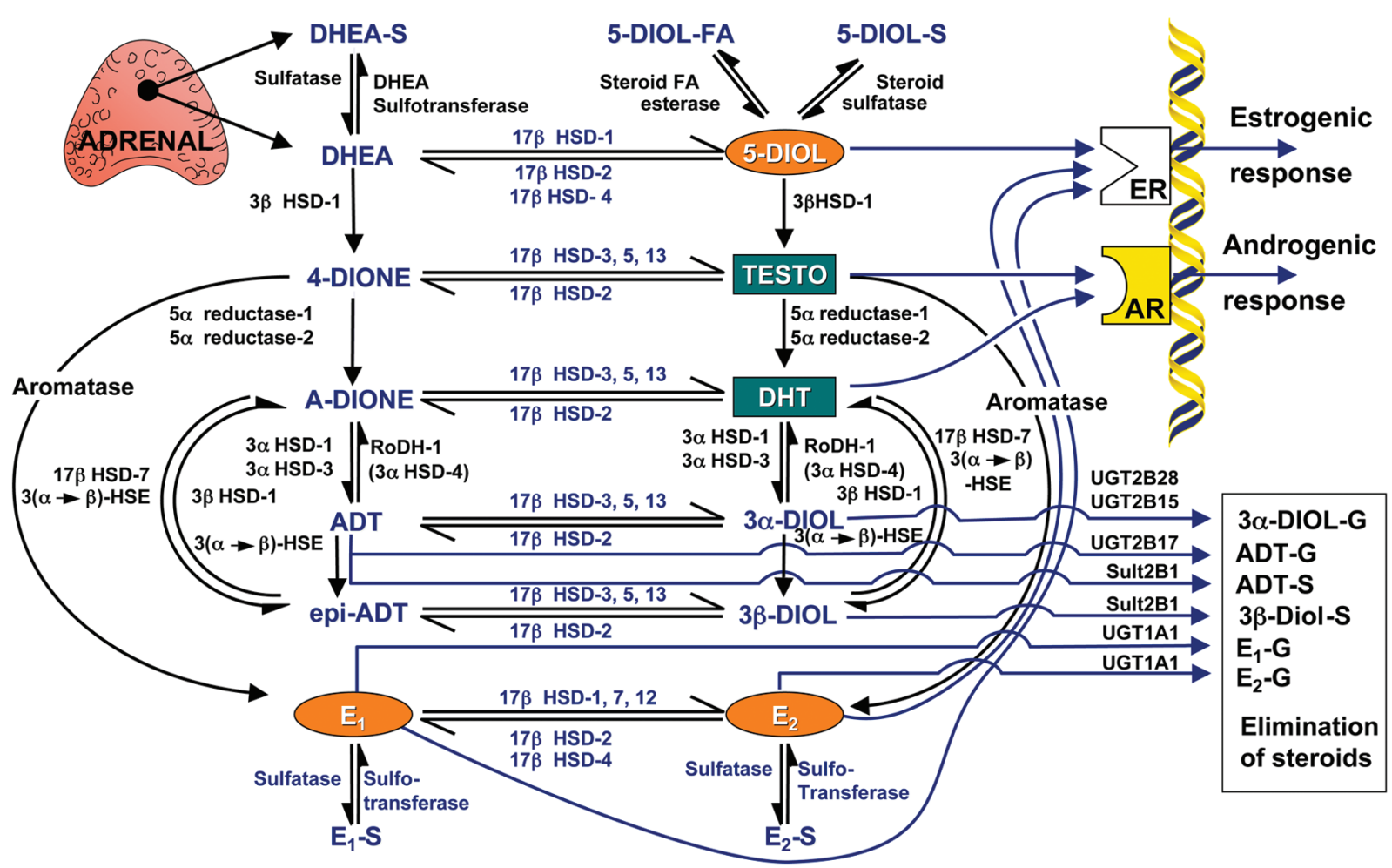

Figure 2 Human steroidogenic and steroid-inactivating enzymes in peripheral intracrine tissues. DHEA, Dehydroepiandrosterone;

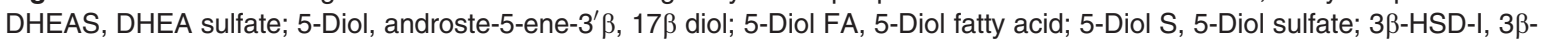
hydroxysteroid dehydrogenase-Type I; 4-Dione, Androstenedione; testo, Testosterone; ER, Estrogen Receptor; AR, Androgen receptor; A-Dione, Androstenedione; Ro-DH-I, Ro-dehydrogenase type I; ADT, Androsterone; UGT, uridine glucuronosyl transferase; ADT-G, ADT glucuronide; $\mathrm{E}_{1}$, Estrone; $\mathrm{E}_{2} 17 \beta$-estradiol.

estrogens is likely to have negative and poorly tolerated consequences in many systems under the long-term conditions of estrogen ablation required for efficient prevention of breast cancer with compounds having an action limited to estrogen formation, as observed with aromatase inhibitors.

\section{Estrogens and breast cancer}

As mentioned above, among all the risk factors, estrogens are well recognized to play the predominant role in breast cancer development and growth (McGuire et al. 1975, Asselin \& Labrie 1978, Davidson \& Lippman 1989). Considerable attention has thus focused on the development of blockers of estrogen biosynthesis and action (Wakeling \& Bowler 1988, Dauvois et al. 1991, de Launoit et al. 1991, Lévesque et al. 1991, Gronemeyer et al. 1992, Labrie et al. 1992a, 1995a, Gauthier et al. 1997) for the treatment of breast cancer.

In fact, a most important characteristic of the endocrine physiology of the mammary gland is that the normal mammary gland, as well as early breast cancer, absolutely require estrogens for proliferation and growth. In agreement with the important role of estrogens, inhibitors of estrogen formation and action have shown very positive results in breast cancer therapy, these benefits being accompanied by an exceptionally good tolerance compared with chemotherapy. Moreover, in addition to the well-recognized benefits of the antiestrogens tamoxifen and fulvestrant, these observations also pertain to inhibitors of estrogen formation, namely the aromatase inhibitors anastrozole, letrozole and exemestane (Bonneterre et al. 2000, Mouridsen et al. 2001, Goss 2002, Goss et al. 2003), as well as to medical castration with LHRH agonists (goserelin, leuprolide, decapeptyl and buserelin). While being much better tolerated, these compounds used alone or in combination usually show results superior to chemotherapy, especially in early disease.

\section{Androgens inhibit breast cancer}

While it is well recognized that estrogens play the predominant role in the development and growth of 
human breast cancer, a series of observations has shown that androgens such as testosterone (Ulrich 1939, Fels 1944, Segaloff et al. 1951, Cooperative Breast Cancer Group 1964), fluoxymesterone (Kennedy 1958, Tormey et al. 1983, Ingle et al. 1991), calusterone (Gordan et al. 1973) and anabolic steroids (Gordan 1976, Segaloff 1977) have an efficacy comparable with that achieved with other types of endocrine manipulation.

Evidence from preclinical studies strongly demonstrates the inhibitory effect of androgens on breast cancer (Labrie et al. 2006). The above-mentioned clinical data are, in fact, well supported by the observation of a synergistic effect of DHEA and the pure antiestrogen EM-800 (a precursor of acolbifene) in preventing the development of dimethylbenz(a)anthracene (DMBA)-induced mammary tumors in the rat (Luo et al. 1997b). Moreover, DHEA shows an almost exclusive androgenic effect on the histomorphology and structure of the rat mammary gland (Sourla et al. 1998), thus suggesting that the inhibitory effect of DHEA is due to its transformation into androgens. Moreover, the effect of androgens as direct inhibitors of breast cancer growth is well supported by the presence of ARs in a large proportion of human breast cancers (Trams \& Maass 1977, Allegra et al. 1979, Bryan et al. 1984, Miller et al. 1985). There is also genetic evidence indicating a protective role of androgens against breast cancer (Wooster et al. 1992, Lobaccaro et al. 1993).

A potent and direct inhibitory effect, at physiological concentrations, of androgens has been observed on the proliferation of human breast cancer cells (Poulin et al. 1988, 1989a,b, Dumont et al. 1989, Simard et al. 1989, 1990). In fact, the first demonstration of a potent and direct inhibitory effect of androgens on human breast cancer growth was obtained in the estrogen-sensitive human breast cancer cell line ZR-75-1 (Poulin et al. 1988). In that study, DHT not only completely blocked the stimulatory effect of $E_{2}$ on cell proliferation but it further reduced cell growth in the absence of estrogens. At low cell density, DHT completely prevented breast cancer cell growth.

It should be added that treatment of ovariectomized monkeys with testosterone decreased the stimulation of mammary epithelial proliferation induced by $\mathrm{E}_{2}$ by about $40 \%$ (Zhou et al. 2000). Moreover, it is possible that part of the increased risk of breast cancer in BRCA-1 mutant patients is associated with the decreased efficiency of the mutated BRCA-1 gene to interact with the AR (Park et al.
2000). It is also pertinent to mention that female athletes and transsexuals taking androgens show atrophy of mammary gland epithelial tissue (Burgess \& Shousha 1993, Korkia \& Stimson 1997).

In addition to the direct inhibitory effect of androgens on mammary epithelial cell proliferation, it is increasingly apparent that mammary cells possess complex regulatory mechanisms that allow for the strict control of the intracellular levels of both stimulatory and inhibitory sex steroids. For instance, our data show that DHT favors the degradation of $E_{2}$ into estrone $\left(\mathrm{E}_{1}\right)$, thus suggesting that the potent antiproliferative activity of DHT in $E_{2}$-stimulated ZR-75-1 human breast cancer cells is, at least partially, exerted on 17 $\beta$-HSD activity (Adams 1985, Poulin et al. 1988, 1989b, Couture et al. 1993). Conversely, we have found that estrogens cause a marked increase in the production of the glucuronidated androgen metabolites androstane $3 \alpha, 17 \beta$-diol glucuronide and androsterone glucuronide in MCF-7 cells, thus decreasing the inhibitory androgenic activity (Roy et al. 1992). In fact, since glucuronidation is the predominant route of androgen inactivation, androgen-inactivating enzymes may constitute an important locus of the regulation of breast cancer growth.

The long series of preclinical and clinical data reviewed by Labrie et al. $(2003 a, 2006)$ indicate that proliferation of both the normal mammary gland and breast cancer results from the balance between the stimulatory effect of estrogens and the inhibitory effect of androgens (Fig. 3). Moreover, the data showing the additive inhibitory action of antiestrogens and androgens suggest that taking advantage of the inhibitory action of androgens on breast cancer proliferation could well improve the efficacy of the currently used and well-tolerated estrogen-deprivation therapies for the treatment and prevention of breast cancer; the most physiological androgen precursor is DHEA which can lead to formation in a tissue-specific manner.

\section{DHEA inhibits breast cancer}

Low circulating levels of DHEA and DHEA-S have been found in patients with breast cancer (Zumoff et al. 1981) and DHEA has been found to exert antioncogenic activity in a series of animal models (Schwartz et al. 1986, Gordon et al. 1987, Li et al. 1993). In fact, DHEA has been shown, in animal model systems, to be an inhibitor of breast, prostate, lung, liver, skin and thyroid carcinogenesis (Ratko et al. 1991, Li et al. 1994, McCormick 


\section{Mammary gland and Breast cancer proliferation}

A Physiological conditions

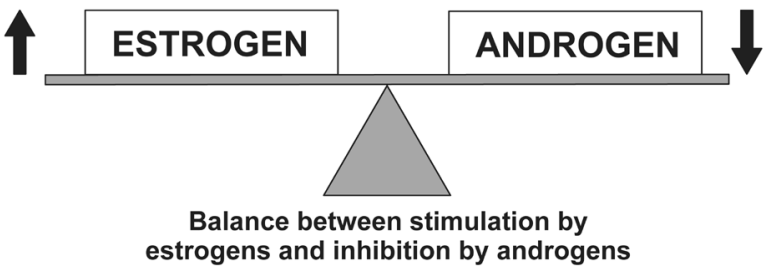

B Combination SERM + DHEA

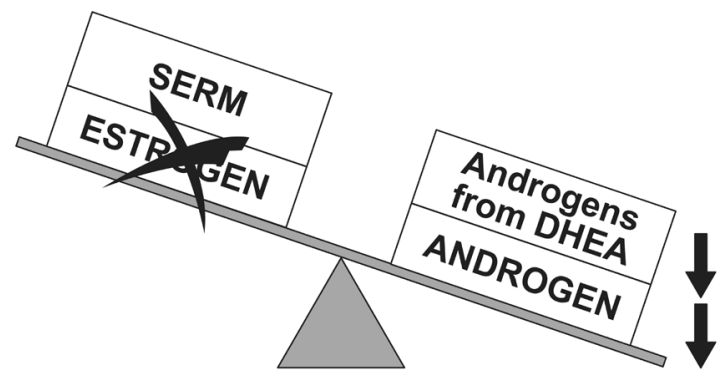

Estrogens blocked by SERM and additional androgens made from exogenous DHEA lead to atrophy

Figure 3 (A) Schematic representation of the balance between the stimulatory action of estrogens and the inhibitory effect of androgens on mammary gland and breast cancer proliferation. In (B) blockade of the action of estrogens by a SERM and addition of androgens made from DHEA both lead to a reduction in mammary gland and breast cancer proliferation and growth.

et al. 1996, Kohama et al. 1997, Lubet et al. 1998, Shilkaitis et al. 2005). Among a series of data showing its inhibitory effect on breast cancer, DHEA blocked the stimulatory effect of $\mathrm{N}$-nitroso$\mathrm{N}$-methylurea on mammary tumor development in the rat by a p16-dependent mechanism (Shilkaitis et al. 2005). DHEA has also been shown to have immunomodulatory effects in vitro (Suzuki et al. 1991) and in vivo in fungal and viral diseases (Rasmussen et al. 1992). On the other hand, a stimulatory effect of DHEA on the immune system has been described in postmenopausal women (Casson et al. 1993).

In order to investigate the possibility that DHEA and its metabolites could have a preventive effect on the development of mammary carcinoma, we have studied the effect of increasing circulating levels of DHEA, constantly released from Silastic implants, on the development of mammary carcinoma induced by DMBA in the rat. DMBA-induced mammary carcinoma in the rat has been widely used as a model of hormone-sensitive breast cancer in women (Asselin et al. 1977, Asselin \& Labrie 1978, Dauvois et al. 1989). Treatment with increasing doses of DHEA delivered constantly by Silastic implants of increasing length and number caused a progressive inhibition of tumor development ( $\mathrm{Li}$ et al. 1993). It is of interest that tumor size in the group of animals treated with the highest dose $(6 \times 3.0 \mathrm{~cm}$ long implants $)$ of DHEA was similar to that found in ovariectomized animals, thus showing a complete blockade of estrogen action by DHEA. Such data clearly demonstrate that circulating levels of the precursor adrenal steroid DHEA, comparable with those observed in normal adult premenopausal women, exert a potent inhibitory effect on the development of mammary carcinoma induced by DMBA in the rat.

\section{Sex steroids and women's health: marked decline in DHEA with age}

There is no medical event related to women's health with a higher negative impact on morbidity (and frequently mortality) than the menopause, a condition closely associated with declining sex steroid availability. The rapid fall in circulating $E_{2}$ at the menopause, coupled with the demonstrated beneficial effects of exogeneous estrogens on menopausal symptoms (Grady et al. 1992, Greendale \& Judd 1993, Lomax \& Schonbaum 1993, Archer et al. 1999) and bone resorption (Weiss et al. 1980, Christiansen et al. 1982, Genant et al. 1990, Harris et al. 1991, Grady et al. 1992, Field et al. 1993, Lindsay 1993, Archer et al. 1999, Women's Health Initiative 2002) has focused most of the efforts of hormone replacement therapy (HRT) on various forms of estrogens (estrogen replacement therapy) as well as on combinations of estrogen and progestin (HRT) in order to avoid the risk of endometrial cancer induced by estrogens administered alone. Classical HRT has, however, recently been seriously questioned or even abandoned by many women following data indicating that the combination of Premarin and Provera (Prempro) causes a 26\% increase in the incidence of breast cancer at 5.2 years of follow-up with a potential negative impact on cardiovascular events (Women's Health Initiative 2002). Similar concerns have also been raised in the Million Women Study (Beral et al. 2005).

The $70-95 \%$ reduction in the formation of DHEA and DHEA-S by the adrenals during aging (Labrie et al. 1997b) results in a dramatic reduction in the formation of androgens and estrogens in peripheral 
target tissues. Among other possible factors, such hormonal changes are believed to play a role in the development of insulin resistance, type 2 diabetes and atherosclerosis (Coleman et al. 1984, Schriock et al. 1988). In fact, a beneficial effect of DHEA on the increase in insulin resistance that occurs with age has been observed (Diamond et al. 1996, Han et al. 1998). Moreover, low DHEA has been associated with atherosclerosis (Alexandersen et al. 1996), aging (Watson et al. 1996), insulin resistance and diabetes (Coleman et al. 1984, Schriock et al. 1988) as well as obesity (MacEwen \& Kurzman 1991, Tchernof et al. 1995a). The 70-95\% reduction in the formation of DHEA and DHEA-S by the adrenal could also well be involved in the pathogenesis of age-related diseases such as obesity (Nestler et al. 1988, MacEwen \& Kurzman 1991, Tchernof et al. 1995a). DHEA may also be related to insulin resistance and hyperinsulinemia through its association with obesity. In agreement with this possibility, we have observed that statistical control for differences in adiposity and abdominal fat accumulation eliminated the association between DHEA and glucose tolerance in men (Tchernof et al. 1995b).

In fact, since DHEA is transformed to both androgens and/or estrogens in peripheral tissues, such a fall in serum DHEA and DHEA-S explains why women at the menopause not only lack estrogen but also suffer deprivation of androgens for quite a few years. It is of interest to mention that in an early publication by Greenblatt et al. (1950), it was indicated that estrogen plus androgen was better than estrogen alone for treatment of the menopause.

\section{SERMs used alone}

\section{Role of SERMs in breast cancer}

The observation that tamoxifen (Fig. 4) reduces the incidence of contralateral breast cancer (Cuzick \& Baum 1985) followed by the study of Powles et al. (1989) has opened the way for the clinical trials that led to the approval of tamoxifen by the Federal Drug Administration (FDA) as the first agent to

\section{SERMs}

Triphenyethylenes

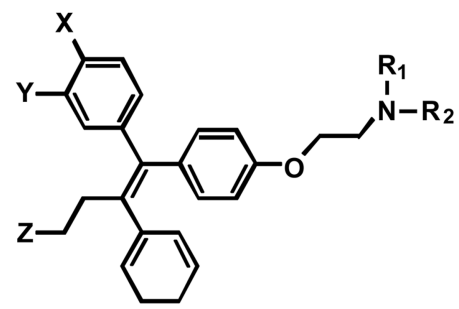

Tamoxifen $\mathrm{X}=\mathrm{Y}=\mathrm{Z}=\mathrm{H}, \mathrm{R}_{1}=\mathrm{R}_{2}=\mathrm{CH}_{3}$ Droloxifene $\mathrm{X}=\mathrm{H}, \mathrm{Y}=\mathrm{OH}, \mathrm{Z}=\mathrm{H}, \mathrm{R}_{1}=\mathrm{R}_{2}=\mathrm{CH}_{3}$ Toremifene $X=Y=H, Z=C l, R_{1}=R_{2}=C_{3}$ Idoxifene $X=I, Y=Z=H, R_{1}, R_{2}=C_{4} H_{8}$

Naphthalenols

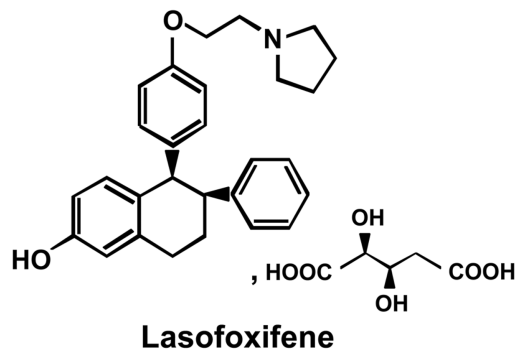
Lasofoxifene
Benzothiophenes<smiles>[X]Oc1ccc(-c2sc3cc(O)ccc3c2[Y])cc1</smiles>

Raloxifene $\mathrm{X}=\mathrm{H}, \mathrm{Y}=-\mathrm{CO}-$ Arzoxifene $\mathrm{X}=\mathrm{CH}_{3}, \mathrm{Y}=-\mathrm{O}$ -
Indoles<smiles>Cc1c(-c2ccc(O)cc2)n(Cc2ccc(OCCN3CCCCC3)cc2)c2ccc(O)cc12</smiles>

Pipendoxifene (ERA 923) $n=1$

Bazedoxifene (TSE 424) $n=2$<smiles>CC1=C(c2ccc(O)cc2)[C@H](c2ccc(OCCN3CCCCC3)cc2)Oc2cc(O)ccc21</smiles>

Acolbifene

Figure 4 Structure of a series of SERMs. 
reduce the risk of breast cancer in high-risk women. Tamoxifen, despite its limitations, thus provided the proof-of-principle data for chemoprevention in breast cancer. Tamoxifen is, in fact, the only FDAapproved drug for breast cancer risk reduction in women who have a minimum 5-year GAIL (Gail score for predicting the risk of developing breast cancer; Gail et al. 1989) estimated risk of breast cancer of $1.66 \%$ and/or lobular carcinoma in situ. The approval was based on the data of the National Surgical Adjuvant Breast and Bowel Project P-1 project where women were randomized to receive 5 years of tamoxifen or placebo. In that trial, women taking tamoxifen had $49 \%$ fewer diagnosed cases of breast cancer with 43.9 versus 22.0 cases per 1000 women followed for 69 months (Fisher et al. 1998). However, as mentioned above, tamoxifen induced some serious adverse events, namely increased incidence of uterine cancer and blood clots, thus limiting its use.

Most encouraging results have been obtained with raloxifene, a SERM having a very low stimulatory effect on the uterus, thus minimizing or avoiding the risk of endometrial cancer. In fact, a $76 \%$ reduction in the risk of diagnosis of breast cancer was observed in osteoporotic women who received raloxifene (Cummings et al. 1999). The STAR trial which compares tamoxifen and raloxifene in the adjuvant setting should define the relative merits of the two drugs.

Two classes of aromatase inhibitors, namely steroidal (e.g. exemestane) and non-steroidal (e.g. anastrozole and letrozole) are now available for the treatment of breast cancer. The data obtained indicate that aromatase inhibitors are more effective than tamoxifen as first-line therapy for postmenopausal women with advanced breast cancer (Nabholtz et al. 2000, Mouridsen et al. 2003, Paridaens et al. 2003). Moreover, as mentioned above, aromatase inhibitors used as adjuvant therapy have shown results superior to tamoxifen in preventing recurrence of the disease in the adjuvant setting (Baum et al. 2003, Goss et al. 2003, Coombes et al. 2004).

Aromatase inhibitors decrease the risk of breast cancer with a reduced risk of uterine cancer and blood clots (Baum et al. 2002, Goss et al. 2003, Coombes et al. 2004). Potential limitations of aromatase inhibitors, however, are related to the observation that these compounds do not block estradiol formation completely (Johannessen et al. 1997, Geisler et al. 2000). Moreover, aromatase inhibitors do not inhibit the formation of the estrogenic 5-diol from DHEA by 17ß-hydroxysteroid dehydrogenase activity (Fig. 2). 5-diol is present in the blood of pre- and postmenopausal women at the levels of $0.49 \pm 0.20 \mathrm{ng} / \mathrm{ml}$ and $0.27 \pm 0.15 \mathrm{ng} /$ $\mathrm{ml}$ respectively. At these concentrations, 5-diol is well known to stimulate the proliferation of human breast cancer cells and other estrogen-sensitive tissues (Adams 1985, Poulin \& Labrie 1986). As mentioned above, aromatase inhibitors thus leave 5-diol free to continue to stimulate breast cancer in the presence of a highly efficient but incomplete inhibition of $E_{2}$ formation. The long-term effects of aromatase inhibitors, moreover, remain to be evaluated.

As has been well demonstrated in prostate cancer, the more efficient blockade of androgens achieved by combining medical (gonadotropin-releasing hormone $(\mathrm{GnRH})$ agonist) or surgical castration with a pure antiandrogen is more efficient than monotherapy, even at the advanced stage (Denis et al. 1993, Caubet et al. 1997, Prostate Cancer Triallists' Collaborative Group 2000, Klotz 2001, Labrie et al. 2002a, 2005b). It is thus likely that the optimal long-term benefits of estrogen blockade in breast cancer will be achieved with optimal estrogen blockade. For comparison, in localized prostate cancer, monotherapy with GnRH agonists alone achieved a one-third decrease in the death rate from prostate cancer (Peto \& Dalesio 2003) while an at least $90 \%$ long-term control and possible cure of the disease was achieved when combining a GnRH agonist with a pure antiandrogen (Labrie et al. 2002a).

That these observations made in men with localized prostate cancer could apply to breast cancer is supported by recent preclinical data showing that the combination of letrozole and fulvestrant is much more efficient than either compound used alone in inhibiting the growth of human MCF-7 (MCF-7 Ca) tumors in nude mice (Jelovac et al. 2005a). In fact, with the combination therapy, tumor size was not only completely blocked but it decreased $45 \%$ below baseline. It is noticeable that these important benefits of combined estrogen blockade observed on breast tumor growth were achieved in the presence of no additional inhibitory effect of the combination of the two drugs on uterine weight, thus indicating that the human breast tumor is more sensitive to low levels of estrogens remaining in the tissue after monotherapy with letrozole or fulvestrant than the normal uterus. It should be mentioned that the model used did not show an additive effect of anastrozole plus tamoxifen or letrozole plus tamoxifen ( $\mathrm{Lu}$ et al. 1999, 
Long et al. 2004), a finding which was confirmed in the trials of arimidex and tamoxifen alone versus their combination in patients with breast cancer (Dowsett et al. 2001). Such data stress the importance of recognizing that all SERMs are different and that the data obtained with tamoxifen cannot be extrapolated to other SERMs having less or no estrogenic activity in the mammary gland and uterus and vice versa.

The underlying principle is that, in sex hormonesensitive cancer, even low sex steroid levels permit continuous cancer cell division with the risk of additional adverse gene mutations and adaptation of other growth pathways, especially the kinase pathways, which more than compensate for the decreased estrogen levels and stimulate cancer cell growth independently of sex steroids. Such an adaptative phenomenon creates resistance to treatment (Schiff et al. 2005). In support of this interpretation, the recent preclinical data mentioned above have shown that the combination of an aromatase inhibitor with an antiestrogen is much more efficient than either compound used alone to inhibit the growth of human breast tumors in nude mice (Jelovac et al. 2005a). The resistance to treatment observed with aromatase inhibitors in advanced breast cancer may, in fact, be related to the incomplete blockade of estrogens achieved with these compounds combined with the residual estrogenic stimulus of 5-diol.

\section{SERMs under development}

Among the SERMs under development, arzoxifene, an analog of raloxifene (Fig. 4) has shown a $10.3 \%$ response rate at the 20 and $50 \mathrm{mg}$ doses in tamoxifen-resistant patients while $26.1 \%$ and $8.0 \%$ response rates were seen at the same doses in tamoxifensensitive patients (Buzdar et al. 2003). On the other hand, in another phase II trial, a 30\% response rate was observed with the $20 \mathrm{mg}$ dose in previously untreated patients with a further $17 \%$ of patients showing stable disease (Baselga et al. 2003). A low $8 \%$ response rate was, however, seen with the $50 \mathrm{mg}$ dose. The compound has moved to phase III where it is compared with tamoxifen (Johnston 2005).

Another SERM in development is acolbifene. Possibly the most important property of acolbifene recognized so far is that it causes the disappearance or cure of $60 \%$ of human breast cancer tumors in nude mice (Gutman et al. 2002). Based upon the data obtained with tamoxifen, the effect of hormone therapy was so far thought to be limited to a tumorostatic action. In other words, following the results originally obtained with tamoxifen (Gottardis et al. 1988), the effect of hormonal therapy has classically been believed to be limited to a slowing of tumor growth or a tumorostatic action. The tumorocidal action of acolbifene is thus a new and most important paradigm of hormone therapy which most likely results from a more complete blockade of the estrogen receptor. Furthermore, acolbifene is the most potent of all available antiestrogens and SERMs in inhibiting the stimulatory effect of estrogens on the proliferation of human breast cancer cells in vitro (Simard et al. 1997a, Labrie et al. 2001a, 2002b). Among seven antiestrogens tested, acolbifene is also the most potent inhibitor of the stimulatory effect of estrogens on the growth of human breast cancer tumors in nude mice (Gutman et al. 2002). Moreover, while resistance to treatment is a major problem in cancer therapy, no resistance is observed with acolbifene in human breast cancer tumors in nude mice (Gutman et al. 2003).

Acolbifene possesses no estrogenic activity in vitro in human Ishikawa endometrial carcinoma cells while all other SERMs tested stimulate alkaline phosphatase activity in these cells (Simard et al. 1997b, Labrie et al. 2001a). Similarly, in the rat, acolbifene has no stimulatory effect on the endometrium, contrary to raloxifene which exerts a significant stimulatory effect (Sato et al. 1998, Martel et al. 2000, Labrie et al. 2002b). In fact, acolbifene blocks the stimulatory effect of all tested SERMs on alkaline phosphatase activity in human Ishikawa endometrial carcinoma cells (Simard et al. 1997b, Labrie et al. 2002b).

The phase II/III clinical program consisted of two studies (ERC-103 and C/197-042) evaluating the efficacy of acolbifene in the treatment of breast cancer in patients who had failed tamoxifen. In study ERC-103, 43 postmenopausal women were enrolled: five patients (one complete response, four partial responses) responded to therapy with acolbifene (Labrie et al. 2004) with a response rate of $12 \%$ while seven $(16 \%)$ patients had stable disease for more than 6 months. These results are numerically comparable with the activity seen with the aromatase inhibitors anastrozole, letrozole and exemestane in the same category of patients.

In the phase III study, the primary objective was to compare the progression-free survival (PFS) between acolbifene and anastrozole treatment in patients with advanced disease who had progressed with tamoxifen. An interim analysis based on a total of 110 events (progression or death) was 
performed. Both the $20 \mathrm{mg}$ and $40 \mathrm{mg}$ doses of acolbifene were compared with anastrozole. Median PFS survival times were 3.19, 4.11 and 4.01 months for acolbifene $(20 \mathrm{mg})$, acolbifene $(40 \mathrm{mg})$ and anastrozole respectively. With such similar findings in the three groups, it was unlikely that acolbifene could be shown to be superior to anastrozole in this category of patients. Based on the results of this interim analysis demonstrating that it was unlikely to meet the original objective of superiority, this study was terminated. An overview of the safety analysis demonstrated a similar toxicity profile to anastrozole with the majority of adverse events being related to disease rather than to treatment. A phase III study in previously untreated metastatic breast cancer patients is planned for this category of patients who are more likely to benefit from the treatment.

While not being a SERM, the preclinical characteristics of fulvestrant have clearly shown that the compound is a pure antagonist of estrogen action in the mammary gland and uterus but is without bone protection or other estrogen-like activity (Howell et al. 2000). In vitro and in vivo studies have shown that tamoxifen-resistant cell lines and tumors remain sensitive to fulvestrant ( $\mathrm{Hu}$ et al. 1993, Osborne et al. 1995). Fulvestrant, a steroidal pure antiestrogen, at the dose used, has been shown to be equivalent to tamoxifen on the initial response or primary treatment of advanced breast cancer (Howell et al. 2004). On the other hand, fulvestrant has been shown to lead to a longer median time to progression compared with anastrozole in patients who had progressed with prior endocrine therapy (Howell et al. 2002, Osborne et al. 2002). Encouraging results have also been observed with fulvestrant in patients progressing under treatment with aromatase inhibitors (Johnston 2005), a phenomenon possibly related to the upregulation of growth factor-signaling pathways (Jelovac et al. 2005b, Sabnis et al. 2005).

\section{Benefits of SERMs on bone}

The US Surgeon General's report on bone health and osteoporosis estimates that over 12 million women and men over 50 years of age will have osteoporosis in the USA by 2010, increasing to 14 million by 2020 . Among women over 50 years of age, the life-time risk of fracture is $40 \%$ and $13 \%$ in men over 50 years of age.

Tamoxifen has been shown to decrease osteoporotic bone fractures (Fisher et al. 1998). Among
Table 1 SERMs in development

1 TSE 424; bazedoxifene (Wyeth)

(a) Osteoporosis (phase III, USA)

Two phase III trials vs raloxifene

(b) HRT in combination with Premarin (phase III, USA; expected NDA 2007)

2 ERA 923; pipendoxifene (Wyeth)

Breast cancer (phase II, February 2005)

3 Acolbifene (Endoceutics)

(a) Breast cancer (phase III)

(b) HRT (phase III)

4 LY381; arzoxifene (Lilly)

(a) Bone fractures (phase III, USA; expected NDA 2010)

(b) Uterine cancer (phase III, prevention)

(c) Breast cancer (compared with tamoxifen)

5 Lasofoxifene (Pfizer)

Osteoporosis (preregistration, USA)

Vaginal atrophy

6 PSK 3471; Prostakan (Sanofi-Aventis)

Osteoporosis

*Partial list; NDA, National Drug Administration.

the SERMs in development (Fig. 4 and Table 1), all of them show beneficial effects on bone loss, at least at the preclinical level. In fact, arzoxifene, bazedoxifene and PSK 3471 are at various stages of clinical development for the prevention and/or treatment of osteoporosis or for the prevention of osteoporotic fractures. While the action of each SERM on other systems, especially the uterus, must be evaluated carefully, it is likely that prevention of bone loss will be achieved with each of these compounds. However, while it is likely that all known SERMs have a potential protective effect on bone in women, one must choose the SERM(s) most likely to have the best protective effect on the breast and endometrium, namely SERM(s) having pure antagonistic activity at the level of the mammary gland and uterus (Labrie et al. 1999, 2001b, 2002c).

\section{SERMs used in combination with DHEA}

\section{Declining androgens with age}

We feel that the increased understanding of androgen and estrogen formation and action in peripheral target tissues (Labrie 1991, Labrie et al. 1992b,c, 1994, 1995b, 1996b, 1997a,b,c,d, Luu-The et al. 1995), as well as our recent observations indicating the predominant role of androgens over that of estrogens in the prevention of bone loss after 
ovariectomy in the rat (Martel et al. 1998) and the observation of a stimulatory action of DHEA on bone mineral density (BMD) in postmenopausal women (Labrie et al. 1997c) have paved the way for timely and potentially highly significant progress in the field of sex steroid replacement therapy at the menopause. This is particularly important at the present time because of the issues raised by the use of estrogens and progestins in this setting (Morales et al. 1994, Diamond et al. 1996, Labrie et al. 1997c, Baulieu 1999, Stomati et al. 2000, Women's Health Initiative 2002, Beral et al. 2005).

Normal women produce an amount of androgen equivalent to about two-thirds of that secreted in men but their production of androgen has already decreased by $60 \%$ at the menopause (Labrie et al. 1997a). As mentioned above, the pool of androgens decreases progressively from the age of 30 years in parallel with the decrease in serum concentrations of DHEA and DHEA-S (Labrie et al. 1997b). Consequently, it appears logical to use SERMs combined with tissue-specific androgenic/estrogenic replacement therapy around and after the menopause. This appears to be the best way to maintain a physiological balance between these two classes of sex steroids in each cell and tissue, an objective which can only be met by the local formation of androgens and estrogens in peripheral tissues from exogeneous DHEA, a tissue-specific precursor of androgens and estrogens.

As mentioned above, the almost exclusive focus on the role of ovarian estrogens has removed attention from the dramatic $70 \%$ fall in circulating DHEA which already occurs between the ages of 20-30 and 40-50 years (Migeon et al. 1957, Vermeulen \& Verdonck 1976, Vermeulen et al. 1982, Orentreich et al. 1984, Bélanger et al. 1994, Labrie et al. 1997b, Beral et al. 2005). Since DHEA is transformed to both androgens and estrogens in peripheral tissues, such a fall in serum DHEA and DHEA-S explains why all women at the menopause not only lack estrogens but are also deprived of androgens. While men are protected from the age-related fall in serum DHEA by the continuous high rate of testosterone secretion by the testicles, the low amount of testosterone of ovarian and adrenal origins has a much less protective effect on the marked fall observed in serum DHEA with age in women.

\section{Synergistic effects on bone}

Since acolbifene and DHEA act by two different mechanisms following interaction with the estrogen and androgen receptors respectively, their combination appears to be well justified for the prevention and treatment of osteoporosis. In fact, in the ovariectomized rat, acolbifene is about ten times more potent than raloxifene in protecting against bone loss (Martel et al. 2000). On the other hand, we have found that DHEA exerts beneficial effects on bone in both intact and ovariectomized female rats (Luo et al. 1997c). Thus, in intact female rats, treatment with DHEA increases BMD of total skeleton, lumbar spine and femur (Luo et al. 1997c). Moreover, we have observed that the combination of a sex steroid precursor (DHEA) and acolbifene not only maintained the stimulatory effect of DHEA on bone formation, but also potentiated the inhibitory effect of the SERM on bone turnover and resorption, as demonstrated by the further decrease in urinary hydroxyproline and calcium excretion (Luo et al. 1997c).

Our preclinical data clearly indicate that DHEA can provide the beneficial effects which are lacking with the use of a SERM alone. While a SERM has effects limited to inhibition of bone resorption, the addition of DHEA stimulates bone formation (an effect not found with a SERM, a bisphosphonate, an estrogen or calcitonin) and further reduces bone resorption above that achieved with acolbifene alone. Moreover, the antiresorptive therapies do not improve all the characteristics of the normal bone, especially the microarchitecture. While the effects of acolbifene on bone have so far only been observed preclinically, treatment with DHEA has been found to increase BMD in postmenopausal women (Labrie et al. 1997b, Baulieu et al. 2000). The observed stimulatory effects of DHEA on BMD in postmenopausal women and the increase in serum osteocalcin, a marker of bone formation, are of particular interest for the prevention and treatment of oestoporosis and indicate a unique activity of DHEA on bone physiology, namely on bone formation (Labrie et al. 1997b).

\section{Synergistic effects on breast}

With regard to the breast, DHEA is known to prevent the development (Luo et al. 1997b) and to inhibit the growth (Li et al. 1993) of dimethylbenz(a)anthracene mammary tumors in the rat. DHEA, in addition, inhibits the growth of human breast cancer xenografts in nude mice (Couillard et al. 1998). Thus, contrary to estrogens and progestins which exert stimulatory effects, DHEA is expected, from a series of preclinical studies, to 
inhibit both the development and the growth of breast cancer in women (Labrie et al. 2003a).

Because of its highly potent and pure antiestrogenic activity, acolbifene should not only eliminate the risk of breast, uterine and ovarian cancer associated with estrogen use (Lacey et al. 2002, Riman et al. 2002, Rodriguez et al. 2002, Women's Health Initiative 2002, Beral et al. 2005) but it may also reduce the spontaneous incidence of these cancers which are diagnosed in $13.3 \%$ (breast cancer), $2.7 \%$ (endometrial cancer) and $1.7 \%$ (ovarian cancer) of women during their lifetime.

\section{Other beneficial effects of the combination of SERM and DHEA}

In addition to an increase in bone formation, DHEA has also been shown, in postmenopausal women, to stimulate vaginal maturation and decrease skin dryness (Labrie et al. 1997b, Baulieu et al. 2000). It is also possible that SERMs could exert additional beneficial effects in postmenopausal women. It seems appropriate to mention some preclinical data obtained with acolbifene which could be very useful if found in women. These data pertain to the reduction of cholesterol and triglycerides, reduced weight gain and increased insulin sensitivity (Luo et al. 1997a, Picard et al. 2000, Lemieux et al. 2003, 2005). The inhibitory effect of acolbifene on serum cholesterol has been found to be due to an increase in the level of the low density lipoprotein receptor in the liver (Lemieux et al. 2005). Acolbifene has also been shown to increase nitric oxide synthesis in endothelial cells (Simoncini et al. 2002).

\section{Conclusion}

Since, as mentioned above, breast cancer metastasizes early compared with prostate cancer (Labrie et al. 2002a, 2005b), prevention is essential in order to achieve a marked decrease in deaths. Without prevention, the majority of breast cancers will continue to be diagnosed at a true advanced stage, despite being clinically localized. For the purposes of comparison, in the field of prostate cancer, more than $99 \%$ of cases can be diagnosed with appropriate screening at the clinically localized stage when cure is a possibility (Labrie et al. 1996a, 2002a, 2005b). Unfortunately, there is no marker for breast cancer equivalent to prostatic-specific antigen for prostate cancer and, much too frequently, breast cancer has already spread at distant sites at the time of diagnosis, thus explaining the recurrence after efficient local therapy by surgery and/or radiotherapy.

Knowing that estrogens play such a crucial role in breast cancer, the two most obvious choices for prevention of the disease are an aromatase inhibitor to block the formation of estrogens (Goss \& Strasser 2001) or a SERM to block the action of estrogens and exert additional benefits of importance for women's health (Jordan 2001). The use of a SERM having multiple actions is now a reality with raloxifene which has been found to treat and prevent osteoporosis while reducing the risk of breast cancer in osteoporotic women (Cummings et al. 1999).

Since the generalized estrogen ablation caused by aromatase inhibitors is unlikely to be acceptable for prevention of breast cancer because of the adverse effects expected under long-term conditions in tissues other than the breast and uterus, it seems clear that major efforts should be devoted to the development of SERMs which have a potent and pure antiestrogenic activity in the mammary gland and uterus while having beneficial effects in other systems of importance for women's health, especially the bones, the cardiovascular system and metabolic processes. As mentioned above, all SERMs are different, and detailed assays must be performed at the preclinical level to ensure the best chances of success of the new compounds in the clinic. It should be remembered, however, that clinical data provide the ultimate and only appropriate proof of efficacy.

In addition to the need to have a SERM with pure antiestrogenic activity in the mammary gland and endometrium, it is also clear that a SERM alone will not meet all the hormonal requirements of women after the menopause. It thus appears reasonable to develop the combination of a SERM with DHEA, a tissue-specific precursor of both androgens and estrogens (Labrie et al. 2005a). That SERMs can efficiently block the effect of estrogens in peripheral tissues has been well demonstrated with studies of acolbifene in the rat (Labrie et al. 2003b); this eliminates the risk of breast and uterine cancer and thus strongly supports the combination approach.

Tissue-specific HRT achieved with the combination of SERM and DHEA could then help to control hot flushes and improve cognitive function and memory (Yaffe 1998), while preventing breast cancer, uterine cancer, ovarian cancer and bone loss as well as fat accumulation and metabolic deterioration (Table 2). One objective is thus to develop a novel strategy for the benefit of peri- and 
Table 2 Effects of a SERM, DHEA and their combination

\begin{tabular}{llll}
\hline End organ & DHEA & SERM & DHEA and SERM \\
\hline Bone density & + & + & + \\
Cholesterol & + & + & + \\
Hot flushes & + & tbd & tbd \\
Breast cancer & + & + & + \\
Endometrial & - & + & + \\
$\quad$ hyperplasia & & & \\
Uterine bleeding & - & + & + \\
Thromboembolic & tbd & tbd & tbd \\
$\quad$ events & & & \\
\hline
\end{tabular}

+, beneficial effect; -, no effect; tbd, to be determined.

${ }^{a}$ Anticipated net effect of DHEA and SERM on target organs.

postmenopausal women, namely a tissue-specific HRT, i.e. DHEA plus acolbifene or another SERM having the minimal characteristics of being a completely pure antagonist of estrogens in the mammary gland and uterus.

\section{Disclosure}

The author is president of Endorecherche, the company responsible for the development of acolbifene and has patents on medical uses of DHEA and its combination with SERMs.

\section{References}

Adams JB 1985 Control of secretion and the function of C19- $\Delta^{5}$ steroids of the human adrenal gland. Molecular and Cellular Endocrinology. 41 1-17.

Alexandersen P, Haarbo J \& Christiansen C 1996 The relationship of natural androgens to coronary heart disease in males: a review. Atherosclerosis 125 1-13.

Allegra JC, Lippman ME, Thompson EB, Simon R, Green L, Barlock A, Green L, Huff KK, Do HM \& Aitken SC 1979 Distribution, frequency and quantitative analysis of estrogen, progesterone, androgen and glucocorticoid receptors in human breast cancer. Cancer Research 39 1447-1454.

Archer DF, Furst K, Tipping D, Dain MP \& Vandepol C 1999 A randomized comparison of continuous combined transdermal delivery of estradiol-norethindrone acetate and estradiol alone for menopause. CombiPatch Study Group. Obstetics and Gynecology 94 498-503.

Asselin J \& Labrie F 1978 Effects of estradiol and prolactin on steroid receptor levels in 7,12-dimethylbenz(a)anthraceneinduced mammary tumors and uterus in the rat. Journal of Steroid Biochemistry 9 1079-1082.

Asselin J, Kelly PA, Caron MG \& Labrie F 1977 Control of hormone receptor levels and growth of 7,12dimethylbenz(a)anthracene-induced mammary tumors by estrogens, progesterone and prolactin. Endocrinology 101 $666-671$.
Baselga J, Llombart-Cussac A, Bellet M, Guillem-Porta V, Enas N, Krejcy K, Carrasco E, Kayitalire L, Kuta M, Lluch A et al. 2003 Randomized, double-blind, multicenter trial comparing two doses of arzoxifene (LY353381) in hormone-sensitive advanced or metastatic breast cancer patients. Annals of Oncology 14 1383-1390.

Baulieu EE 1999 Neuroactive neurosteroids: dehydroepiandrosterone (DHEA) and DHEA sulphate. Acta Paediatrica 88 (Suppl) 78-80.

Baulieu EE, Thomas G, Legrain S, Lahlou N, Roger M, Debuire B, Faucounau V, Girard L, Hervy MP, Latour F et al. 2000 Dehydroepiandrosterone (DHEA), DHEA sulfate, and aging: contribution of the DHEAge study to a sociobiomedical issue. PNAS 97 4279-4284.

Baum M, Budzar AU, Cuzick J, Forbes J, Houghton JH, Klijn JG \& Sahmoud T 2002 Anastrozole alone or in combination with tamoxifen versus tamoxifen alone for adjuvant treatment of postmenopausal women with early breast cancer: first results of the ATAC randomised trial. Lancet 359 2131-2139.

Baum M, Buzdar A, Cuzick J, Forbes J, Houghton J, Howell A \& Sahmoud T 2003 Anastrozole alone or in combination with tamoxifen versus tamoxifen alone for adjuvant treatment of postmenopausal women with early-stage breast cancer: results of the ATAC (Arimidex, Tamoxifen Alone or in Combination) trial efficacy and safety update analyses. Cancer 98 1802-1810.

Bélanger A, Candas B, Dupont A, Cusan L, Diamond P, Gomez JL \& Labrie F 1994 Changes in serum concentrations of conjugated and unconjugated steroids in 40- to 80-year-old men. Journal of Clinical Endocrinology and Metabolism 79 1086-1090.

Beral V, Bull D \& Reeves G 2005 Endometrial cancer and hormone-replacement therapy in the Million Women Study. Lancet 365 1543-1551.

Bonneterre J, Thurlimann B, Robertson JF, Krzakowski M, Mauriac L, Koralewski P, Vergote I, Webster A, Steinberg M \& von Euler M 2000 Anastrozole versus tamoxifen as first-line therapy for advanced breast cancer in 668 postmenopausal women: results of the Tamoxifen or Arimidex Randomized Group Efficacy and Tolerability study. Journal of Clinical Oncology 18 3748-3757.

Bryan RM, Mercer RJ, Bennett RC, Rennie GC, Lie TH \& Morgan FJ 1984 Androgen receptors in breast cancer. Cancer 54 2436-2440.

Burgess HE \& Shousha S 1993 An immunohistochemical study of the long-term effects of androgen administration on female-to-male transsexual breast: a comparison with normal female breast and male breast showing gynaecomastia. Journal of Pathology 170 37-43.

Buzdar A, O'Shaughnessy JA, Booser DJ, Pippen JE Jr, Jones SE, Munster PN, Peterson P, Melemed AS, Winer E \& Hudis C 2003 Phase II, randomized, double-blind study of two dose levels of arzoxifene in patients with locally advanced or metastatic breast cancer. Journal of Clinical Oncology 21 1007-1014.

Casson PR, Andersen RN, Herrod HG, Stentz FB, Straughn AB, Abraham GE \& Buster JE 1993 Oral 
dehydroepiandrosterone in physiologic doses modulates immune function in postmenopausal women. American Journal of Obstetics and Gynecology 169 1536-1539.

Caubet JF, Tosteson TD, Dong EW, Naylon EM, Whiting GW, Ernstoff MS \& Ross SD 1997 Maximum androgen blockade in advanced prostate cancer: a meta-analysis of published randomized controlled trials using nonsteroidal antiandrogens. Urology 49 71-78.

Christiansen C, Christensen MS, Larsen NE \& Transbol IB 1982 Pathophysiological mechanisms of estrogen effect on bone metabolism. Dose-response relationships in early postmenopausal women. Journal of Clinical Endocrinology and Metabolism 55 1124-1130.

Clarke R, Leonessa F, Welch JN \& Skaar TC 2001 Cellular and molecular pharmacology of antiestrogen action and resistance. Pharmacological Reviews 53 25-71.

Coleman DL, Schwizer RW \& Leiter EH 1984 Effect of genetic background on the therapeutic effects of dehydroepiandrosterone (DHEA) in diabetes-obesity mutants and in aged normal mice. Diabetes 33 26-32.

Coleman RE, Banks LM, Hall E, Price D, Girgis S, Bliss JM \& Coombes RC 2004 Intergroup Exemestane Study: 1 year results of the bone sub-protocol. Breast Cancer Research and Treatment $\mathbf{8 8} \mathrm{S} 35$.

Coombes RC, Hall E, Gibson LJ, Paridaens R, Jassem J, Delozier T, Jones SE, Alvarez I, Bertelli G, Ortmann O et al. 2004 A randomized trial of exemestane after two to three years of tamoxifen therapy in postmenopausal women with primary breast cancer. New England Journal of Medicine 350 1081-1092.

Cooperative Breast Cancer Group 1964 Testosterone propionate therapy of breast cancer. Journal of the American Medical Association 188 1069-1072.

Couillard S, Labrie C, Bélanger A, Candas B, Pouliot F \& Labrie F 1998 Effect of dehydroepiandrosterone and the antiestrogen EM-800 on the growth of human ZR-75-71 breast cancer xenografts. Journal of the National Cancer Institute $90772-778$.

Couture P, Thériault C, Simard J \& Labrie F 1993 Androgen receptor-mediated stimulation of $17 \beta$-hydroxysteroid dehydrogenase activity by dihydrotestosterone and medroxyprogesterone acetate in ZR-75-71 human breast cancer cells. Endocrinology 132 179-185.

Cummings SR, Eckert S, Krueger KA, Grady D, Powles TJ, Cauley JA, Norton L, Nickelsen T, Bjarnason NH, Morrow M et al. 1999 The effect of raloxifene on risk of breast cancer in postmenopausal women: results from the MORE randomized trial. Multiple Outcomes of Raloxifene Evaluation. Journal of the American Medical Association 281 2189-2197.

Cuzick J \& Baum M 1985 Tamoxifen and contralateral breast cancer. Lancet ii 282.

Dauvois S, Li S, Martel C \& Labrie F 1989 Inhibitory effect of androgens on DMBA-induced mammary carcinoma in the rat. Breast Cancer Research and Treatment 14 299-306.

Dauvois S, Geng CS, Lévesque C, Mérand Y \& Labrie F 1991 Additive inhibitory effects of an androgen and the antiestrogen EM-170 on estradiol-stimulated growth of human ZR-75-71 breast tumors in athymic mice. Cancer Research 51 3131-3135.

Davidson NE \& Lippman ME 1989 The role of estrogens in growth regulation of breast cancer. Critical Reviews in Oncology 1 89-111.

Denis L, Carnelro de Moura J, Bono A, Sylvester R, Whelan P, Newling D \& Depauw M 1993 Goserelin acetate and flutamide vs bilateral orchiectomy: a phase III EORTC trial (30853). EORTC GU Group and EORTC Data Center. Urology 42 119-129.

Diamond P, Cusan L, Gomez JL, Bélanger A \& Labrie F 1996 Metabolic effects of 12-month percutaneous DHEA replacement therapy in postmenopausal women. Journal of Endocrinology $150 \mathrm{~S} 43-\mathrm{S} 50$.

Dowsett M, Cuzick J, Howell A \& Jackson I 2001

Pharmacokinetics of anastrozole and tamoxifen alone, and in combination, during adjuvant endocrine therapy for early breast cancer in postmenopausal women: a sub-protocol of the 'Arimidex and tamoxifen alone or in combination' (ATAC) trial. British Journal of Cancer 85 317-324.

Dumont M, Dauvois S, Simard J, Garcia T, Schachter B \& Labrie F 1989 Antagonism between estrogens and androgens on GCDFP-15 gene expression in ZR-75-71 cells and correlation between GCDFP-15 and estrogen as well as progesterone receptor expression in human breast cancer. Journal of Steroid Biochemistry $\mathbf{3 4}$ 397-402.

EBCTCG 2005 Effects of chemotherapy and hormonal therapy for early breast cancer on recurrence and 15-year survival: an overview of the randomised trials. Lancet $\mathbf{3 6 5}$ 1687-1717.

Fels E 1944 Treatment of breast cancer with testosterone propionate. A preliminary report. Journal of Clinical Endocrinology 4 121-125.

Field CS, Ory SJ, Wahner HW, Herrmann RR, Judd HL \& Riggs BL 1993 Preventive effects of transdermal 17-beta estradiol on osteoporotic changes after surgical menopause: a two year placebo controlled trial. American Journal of Obstetics and Gynecology 168 114-121.

Fisher B, Costantino C, Redmond ER, Fisher D, Wickerham L, Cronin WM \& NSABP Contributors 1994 Endometrial cancer in tamoxifen-treated breast cancer patients: findings from the National Surgical Adjuvant Breast and Bowel Project (NSABP) B-14. Journal of the National Cancer Institute 86 527-537.

Fisher B, Dignam J, Bryant J, DeCillis A, Wickerham DL, Wolmark N, Costantino J, Redmond C, Fisher ER, Bowman DM et al. 1996 Five versus more than five years of tamoxifen therapy for breast cancer patients with negative lymph nodes and estrogen-positive tumors. Journal of the National Cancer Institute 88 1529-1542.

Fisher B, Costantino JP, Lawrence Wickerham D, Redmond CK, Kavanah M, Cronin WM, Vogel V, Robidoux A, Dimitrov N, Atkins J et al. 1998 Tamoxifen for prevention of breast cancer: report of the National Surgical Adjuvant Breast and Bowel Project P-1 study. Journal of the National Cancer Institute 90 1371-1388. 
Fisher B, Dignam J, Bryant J \& Wolmark N 2001 Five versus more than five years of tamoxifen for lymph node-negative breast cancer: updated findings from the National Surgical Adjuvant Breast and Bowel Project B-14 randomized trial. Journal of the National Cancer Institute 93 684-690.

Gail MH, Brinton LA, Byar DP, Corle DK, Green SB, Schairer C \& Mulvihill JJ 1989 Projecting individualized probabilities of developing breast cancer for white females who are being examined annually. Journal of the National Cancer Institute 81 1879-1886.

Gauthier S, Caron B, Cloutier J, Dory YL, Favre A, Larouche D, Mailhot J, Ouellet C, Schwerdtfeger A, Leblanc G et al. 1997 (S)-(+)-4-[7-(2,2-dimethyl-1oxopropoxy)-4-methyl-2-[4-[2-(1-piperidinyl)ethoxy]phenyl]-2H-1-benzopyran-3-yl]-phenyl 2,2dimethylpropanoate (EM-800): a highly potent, specific, and orally active nonsteroidal antiestrogen. Journal of Medicinal Chemistry 40 2117-2122.

Geisler J, Anker G, Dowsett M \& Lonning PE 2000 Letrozole supresses plasma estrogen levels in breast cancer patients more completely than anastrozole. Proceedings of the American Association of Clinical Oncology 19 102a.

Genant HK, Baylink DJ, Gallagher JC, Harris ST, Steiger P \& Herber M 1990 Effect of estrone sulfate on postmenopausal bone loss. Obstetics and Gynecology 76 579-584.

Gordan GS 1976 Anabolic-androgenic steroids. In Handbook of Experimental Pharmacology, pp 499-513. Ed. CD Kochakian. New York: Springer-Verlag.

Gordan GS, Halden A, Horn Y, Fuery JJ, Parsons RJ \& Walter RM 1973 Calusterone (7 $\beta, 17 \alpha$-dimethyltestosterone) as primary and secondary therapy of advanced breast cancer. Oncology 28 138-146.

Gordon GB, Shantz LM \& Talalay P 1987 Modulation of growth, differentiation and carcinogenesis by dehydroepiandrosterone. Advances in Enzyme Regulation 26 355-382.

Goss P 2002 Anti-aromatase agents in the treatment and prevention of breast cancer. Cancer Control 9 2-8.

Goss PE \& Strasser K 2001 Aromatase inhibitors in the treatment and prevention of breast cancer. Journal of Clinical Oncology 19 881-894.

Goss PE, Ingle JN, Martino S, Robert NJ, Muss HB, Piccart MJ, Castiglione M, Tu D, Shepherd LE, Pritchard KI et al. 2003 A randomized trial of letrozole in postmenopausal women after five years of tamoxifen therapy for early-stage breast cancer. New England Journal of Medicine 19 1793-1802.

Gottardis MM, Robinson SP, Satyaswaroop PG \& Jordan VC 1988 Contrasting actions of tamoxifen on endometrial and breast tumor growth in the athymic mouse. Cancer Research 48 812-815.

Grady D, Rubin SM, Petitti DB, Fox CS, Black D, Ettinger B, Ernster VL \& Cummings SR 1992 Hormone therapy to prevent disease and prolong life in postmenopausal women. Annals of Internal Medicine 117 1016-1037.
Greenblatt RB, Barfield WE, Garner JF, Calk GL \& Harrod JP Jr 1950 Evaluation of an estrogen, androgen, estrogen-androgen combination, and a placebo in the treatment of the menopause. Journal of Clinical Endocrinology and Metabolism 10 1547-1558.

Greendale GA \& Judd HL 1993 The menopause: health implications and clinical management. Journal of the American Geriatric Society 41 426-436.

Gronemeyer H, Benhamou B, Berry M, Bocquel MT, Gofflo D, Garcia T, Lerouge T, Metzger D, Meyer ME, Tora L et al. 1992 Mechanisms of antihormone action. Journal of Steroid Biochemistry and Molecular Biology 41 217-221.

Gutman M, Couillard S, Roy J, Labrie F, Candas B \& Labrie C 2002 Comparison of the effects of EM-652 (SCH 57068), tamoxifen, toremifene, droloxifene, idoxifene, GW-5638 and raloxifene on the growth of human ZR-75-71 breast tumors in nude mice. International Journal of Cancer 99 273-278.

Gutman M, Couillard S, Labrie F, Candas B \& Labrie C 2003 Effect of treatment sequence with radiotherapy and the antiestrogen EM 800 on the growth of ZR 751 human mammary carcinoma in nude mice. International Journal of Cancer 103 268-276.

Han DH, Hansen PA, Chen MM \& Holloszy JO 1998 DHEA treatment reduces fat accumulation and protects against insulin resistance in male rats. Journal of Gerontology: A Biological and Medical Science $\mathbf{5 3}$ B19-B24.

Harris ST, Genant HK, Baylink DJ, Gallagher JC, Karp SK, McConnell MA, Green EM \& Stoll RW 1991 The effects of estrone (Ogen) on spinal bone density of postmenopausal women. Archives of Internal Medicine $\mathbf{1 5 1}$ 1980-1984.

Howell A, Osborne CK, Morris C \& Wakeling AE 2000 ICI 182,780 (Faslodex): development of a novel, 'pure' antiestrogen. Cancer 89 817-825.

Howell A, Robertson J, Quaresma Albano J, Aschermannova A, Mauriac L, Kleeberg UR, Vergote I, Erikstein B, Webster A \& Morris C 2002 Fulvestrant, formerly ICI 182,780 , is as effective as anastrozole in postmenopausal women with advanced breast cancer progression after prior endocrine treatment. Journal of Clinical Oncology 20 3396-3403.

Howell A, Robertson JF, Abram P, Lichinitser MR, Elledge R, Bajetta E, Watanabe T, Morris C, Webster A, Dimery I et al. 2004 Comparison of fulvestrant versus tamoxifen for the treatment of advanced breast cancer in postmenopausal women previously untreated with endocrine therapy: a multinational, double-blind, randomized trial. Journal of Clinical Oncology 22 $1605-1613$.

Howell A, Cuzick J, Baum M, Buzdar A, Dowsett M, Forbes JF, Hoctin-Boes G, Houghton J, Locker GY \& Tobias JS 2005 Results of the ATAC (Arimidex, Tamoxifen, Alone or in Combination) trial after completion of 5 years' adjuvant treatment for breast cancer. Lancet 365 60-62. 
Hu XF, Veroni M, De Luise M, Wakeling A, Sutherland R, Watts CK \& Zalcberg JR 1993 Circumvention of tamoxifen resistance by the pure anti-estrogen ICI 182,780. International Journal of Cancer 55 873-876.

Ingle JN, Twito DI, Schaid DJ, Cullinan SA, Krook JE, Mailliard JA, Tschetter LK, Long HJ, Gerstner JG, Windschitl HE et al. 1991 Combination hormonal therapy with tamoxifen plus fluoxymesterone versus tamoxifen alone in postmenopausal women with metastatic breast cancer. A phase II study. Cancer 67 886-891.

Jaiyesimi IA, Buzdar AU, Decker DA \& Hortobagyi GN 1995 Use of tamoxifen for breast cancer: twenty-eight years later. Journal of Clinical Oncology 13 513-529.

Jakesz R, Jonat W, Gnant M, Mittlboeck M, Greil R, Tausch C, Hilfrich J, Kwasny W, Menzel C, Samonigg H et al. 2005 Switching of postmenopausal women with endocrine-responsive early breast cancer to anastrozole after 2 years' adjuvant tamoxifen: combined results of ABCSG trial 8 and ARNO 95 trial. Lancet 366 455-462.

Jelovac D, Macedo L, Goloubeva OG, Handratta V \& Brodie AM 2005a Additive antitumor effect of aromatase inhibitor letrozole and antiestrogen fulvestrant in a postmenopausal breast cancer model. Cancer Research $\mathbf{6 5}$ 5439-5444.

Jelovac D, Sabnis G, Long BJ, Macedo L, Goloubeva OG \& Brodie AM 2005b Activation of mitogen-activated protein kinase in xenografts and cells during prolonged treatment with aromatase inhibitor letrozole. Cancer Research $\mathbf{6 5}$ 5380-5389.

Johannessen DC, Engan T, Di Salle E, Zurlo MG, Paolini J, Ornati G, Piscitelli G, Kvinnsland S \& Lonning PE 1997 Endocrine and clinical effects of exemestane (PNU 155971), a novel steroidal aromatase inhibitor, in postmenopausal breast cancer patients: a phase I study. Clinical Cancer Research 3 1101-1108.

Johnston SR 2005 Endocrinology and hormone therapy in breast cancer: selective oestrogen receptor modulators and downregulators for breast cancer - have they lost their way? Breast Cancer Research 7 119-130.

Jones J, Vukelja S \& Cantrell J 2003 A planned comparison of menopausal symptoms during year 1 in patients receiving either examestane or tamoxifene ina double-blind adjuvant hormonal study. Breast Cancer Research and Treatment 82 S31.

Jordan PH Jr 2001 Longterm results of esophageal myotomy for achalasia. Journal of the American College of Surgeons $193137-145$.

Kennedy BJ 1958 Fluxymesterone therapy in treatment of advanced breast cancer. New England Journal of Medicine $259673-675$.

Klotz L 2001 Combined androgen blockade in prostate cancer: meta-analyses and associated issues. British Journal of Urology 87 806-813.

Kohama T, Terada S, Suzuki N \& Inoue M 1997 Effects of dehydroepiandrosterone and other sex steroid hormones on mammary carcinogenesis by direct injection of 7,12-dimethylbenz(a) anthracene (DMBA) in hyperprolactinemic female rats. Breast Cancer Research and Treatment 43 105-115.

Korkia P \& Stimson GV 1997 Indications of prevalence, practice and effects of anabolic steroid use in Great Britain. International Journal of Sports Medicine 18 557-562.

Labrie C, Bélanger A \& Labrie F 1988 Androgenic activity of dehydroepiandrosterone and androstenedione in the rat ventral prostate. Endocrinology 123 1412-1417.

Labrie C, Martel C, Dufour JM, Lévesque C, Mérand Y \& Labrie F $1992 a$ Novel compounds inhibit estrogen formation and action. Cancer Research 52 610-615.

Labrie F 1991 Intracrinology. Molecular and Cellular Endocrinology 78 C113-C118.

Labrie F, Dupont A \& Bélanger A 1985 Complete androgen blockade for the treatment of prostate cancer. In Important Advances in Oncology, pp 193-217. Eds VT de Vita, S Hellman \& SA Rosenberg. Philadelphia: J.B. Lippincott.

Labrie F, Simard J, Luu-The V, Bélanger A \& Pelletier G $1992 b$ Structure, function and tissue-specific gene expression of $3 \beta$-hydroxysteroid dehydrogenase/5-ene-4ene isomerase enzymes in classical and peripheral intracrine steroidogenic tissues. Journal of Steroid Biochemistry and Molecular Biology 43 805-826.

Labrie F, Simard J, Luu-The V, Pelletier G, Bélanger A, Lachance Y, Zhao HF, Labrie C, Breton N, de Launoit Y et al. 1992 c Structure and tissue-specific expression of $3 \beta$-hydroxysteroid dehydrogenase/5-ene-4-ene isomerase genes in human and rat classical and peripheral steroidogenic tissues. Journal of Steroid Biochemistry and Molecular Biology 41 421-435.

Labrie F, Simard J, Luu-The V, Pelletier G, Belghmi K \& Bélanger A 1994 Structure, regulation and role of $3 \beta$-hydroxysteroid dehydrogenase, $17 \beta$-hydroxysteroid dehydrogenase and aromatase enzymes in formation of sex steroids in classical and peripheral intracrine tissues. In Hormone, Enzymes and Receptors, pp 451-474. Eds MC Sheppard \& PM Stewart. London: Baillière's Clinical Endocrinology and Metabolism, Baillière Tindall Ltd.

Labrie F, Li S, Labrie C, Lévesque C \& Mérand Y 1995 a Inhibitory effect of a steroidal antiestrogen (EM-170) on estrone-stimulated growth of 7,12 dimethylbenz(a)anthracene (DMBA)-induced mammary carcinoma in the rat. Breast Cancer Research and Treatment 33 237-244.

Labrie F, Candas B, Cusan L, Gomez JL, Diamond P, Suburu R \& Lemay M 1996a Diagnosis of advanced or noncurable prostate cancer can be practically eliminated by prostate-specific antigen. Urology 47 212-217.

Labrie F, Simard J, Luu-The V, Bélanger A, Pelletier G, Morel Y, Mebarki F, Sanchez R, Durocher F, Turgeon C et al. $1996 b$ The 3 $\beta$-hydroxysteroid dehydrogenase/ isomerase gene family: lessons from type II $3 \beta$-HSD congenital deficiency. In Signal Transduction in Testicular Cells. Ernst Schering Research Foundation Workshop, pp 185-218. Eds V Hansson, FO Levy \& K Taskén. Berlin, Heidelberg, New York: Springer-Verlag. 
Labrie F, Belanger A, Cusan L \& Candas B 1997 a Physiological changes in dehydroepiandrosterone are not reflected by serum levels of active androgens and estrogens but of their metabolites: intracrinology. Journal of Clinical Endocrinology and Metabolism 82 2403-2409.

Labrie F, Bélanger A, Cusan L, Gomez JL \& Candas B 1997b Marked decline in serum concentrations of adrenal C19 sex steroid precursors and conjugated androgen metabolites during aging. Journal of Clinical Endocrinology and Metabolism 82 2396-2402.

Labrie F, Diamond P, Cusan L, Gomez JL \& Bélanger A 1997 c Effect of 12-month DHEA replacement therapy on bone, vagina, and endometrium in postmenopausal women. Journal of Clinical Endocrinology and Metabolism 82 3498-3505.

Labrie F, Luu-The V, Lin SX, Labrie C, Simard J, Breton R \& Bélanger A 1997d The key role of $17 \beta$-HSDs in sex steroid biology. Steroids 62 148-158.

Labrie F, Labrie C, Bélanger A, Simard J, Gauthier S, Luu-The V, Mérand Y, Giguère V, Candas B, Luo S et al. 1999 EM-652 (SCH 57068), a third generation SERM acting as pure antiestrogen in the mammary gland and endometrium. Journal of Steroid Biochemistry and Molecular Biology 69 51-84.

Labrie F, Simard J, Labrie C \& Bélanger A 2001a EM-652 (SCH 57068), a pure SERM in the mammary gland and endometrium. Références en Gynécologie Obstétrique $\mathbf{8}$ 331-336.

Labrie F, Labrie C, Bélanger A, Giguère V, Simard J, Mérand Y, Gauthier S, Luu-The V, Candas B, Martel C et al. $2001 b$ Pure selective estrogen receptor modulators, new molecules having absolute cell specificity ranging from pure antiestrogenic to complete estrogen-like activities. In Advances in Protein Chemistry: Drug Discovery and Design, pp 293-368. Ed. EM Scolnick. San Diego, CA: Academic Press.

Labrie F, Candas B, Gomez JL \& Cusan L 2002a Can combined androgen blockade provide long-term control or possible cure of localized prostate cancer? Urology 60 115-119.

Labrie F, Labrie C, Bélanger A \& Simard J 2002b Third and fourth generation SERMs. In Selective Estrogen Receptor Modulators: Research and Clinical Applications, pp 167-187. Eds A Manni \& M Verderame. Totowa, NJ: Humana Press.

Labrie F, Labrie C, Bélanger A \& Simard J 2002c Contemporary endocrinology: selective estrogen receptor modulator: research and clinical application. In Contemporary Endocrinology, pp 167-187. Eds AM \& MF Verderame. Totowa, NJ: Humana Press.

Labrie F, Luu-the V, Labrie C, Bélanger A, Simard J, Lin S-X \& Pelletier G $2003 a$ Endocrine and intracrine sources of androgens in women: inhibition of breast cancer and other roles of androgens and their precursor dehydroepiandrosterone. Endocrine Reviews 24 $152-182$.
Labrie F, El-Alfy M, Berger L, Labrie C, Martel C, Bélanger A, Candas B \& Pelletier G 2003b The combination of a novel SERM with an estrogen protects the mammary gland and uterus in a rodent model: the future of postmenopausal women's health? Endocrinology 144 4700-4706.

Labrie F, Champagne P, Labrie C, Bélanger A, Roy J, Laverdière J, Deschênes L, Provencher L, Potvin M, Drolet Y et al. 2004 Activity and safety of the orally active pure antiestrogen EM-800 (SCH 57050) in tamoxifen-resistant breast cancer. Journal of Clinical Oncology 22 864-871.

Labrie F, Luu-The V, Bélanger A, Lin S-X, Simard J \& Labrie C $2005 a$ Is DHEA a hormone? Starling review. Journal of Endocrinology 187 169-196.

Labrie F, Bélanger A, Candas B, Cusan L, Gomez JL, Labrie C, Luu-The V \& Simard J 2005b GnRH agonists in the treatment of prostate cancer. Endocrine Reviews $\mathbf{2 6}$ 361-379.

Labrie F, Poulin R, Simard J, Luu-The V, Labrie C \& Bélanger A 2006 Androgens, DHEA and breast cancer. In Androgens and Reproductive Aging, pp 113-135. Ed. T Gelfand. Oxford: Taylor and Francis.

Labrie Y, Durocher F, Lachance Y, Turgeon C, Simard J, Labrie C \& Labrie F $1995 b$ The human type II $17 \beta$-hydroxysteroid dehydrogenase gene encodes two alternatively-spliced messenger RNA species. DNA and Cell Biology 14 849-861.

Lacey JV, Mink PJ, Lubin JH, Sherman ME, Troisi R, Hartge P, Schatzkin A \& Schairer C 2002 Menopausal hormone replacement therapy and risk of ovarian cancer. Journal of the American Medical Association 288 334-341.

de Launoit Y, Dauvois S, Dufour M, Simard J \& Labrie F 1991 Inhibition of cell cycle kinetics and proliferation by the androgen $5 \alpha$-dihydrotestosterone and antiestrogen $\mathrm{N}$, n-butyl-N-methyl-11-(16 ${ }^{\prime} \alpha$-chloro-3',17 $\beta$-dihydroxyestra- $1^{\prime}, 3^{\prime}, 5^{\prime}-\left(10^{\prime}\right)$ triene- $7^{\prime} \alpha$-yl)undecanamide in human breast cancer ZR-75-71 cells. Cancer Research $\mathbf{5 1}$ 2797-2802.

Lemieux C, Picard F, Labrie F, Richard D \& Deshaies Y 2003 The estrogen antagonist EM-652 and dehydroepiandrosterone prevent diet- and ovariectomyinduced obesity. Obesity Research 11 477-490.

Lemieux C, Gelinas Y, Lalonde J, Labrie F, Cianflone K \& Deshaies Y 2005 Hypolipidemic action of the SERM acolbifene is associated with decreased liver MTP and increased SR-BI and LDL receptors. Journal of Lipid Research 46 1285-1294.

Lévesque C, Mérand Y, Dufour JM, Labrie C \& Labrie F 1991 Synthesis and biological activity of new halo-steroidal antiestrogens. Journal of Medicinal Chemistry 34 1624-1630.

Li S, Yan X, Bélanger A \& Labrie F 1993 Prevention by dehydroepiandrosterone of the development of mammary carcinoma induced by 7,12-dimethylbenz(a)anthracene (DMBA) in the rat. Breast Cancer Research and Treatment 29 203-217. 
Li S, Yan X, Belanger A \& Labrie F 1994 Prevention by dehydroepiandrosterone of the development of mammary carcinoma induced by 7,12-dimethylbenz(a)anthracene (DMBA) in the rat. Breast Cancer Research and Treatment 29 203-217.

Lindsay R 1993 Hormone replacement therapy for prevention and treatment of osteoporosis. American Journal of Medicine 95 37S-39S.

Lobaccaro JM, Lumbroso S, Belon C, Galtier-Dereure F, Bringer J, Lesimple T, Namer M, Cutuli BF, Pujol H \& Sultan C 1993 Androgen receptor gene mutation in male breast cancer. Human and Molecular Genetics 2 1799-1802.

Lomax P \& Schonbaum E 1993 Postmenopausal hot flushes and their management. Pharmacological Therapy 57 $347-358$.

Long BJ, Jelovac D, Handratta V, Thiantanawat A, MacPherson N, Ragaz J, Goloubeva OG \& Brodie AM 2004 Therapeutic strategies using the aromatase inhibitor letrozole and tamoxifen in a breast cancer model. Journal of the National Cancer Institute 96 456-465.

Lonning PE, Geisler J, Krag LE, Erikstein B, Bremnes Y, Hagen AI, Schlichting E, Lien EA, Ofjord ES, Paolini J et al. 2005 Effects of exemestane administered for 2 years versus placebo on bone mineral density, bone biomarkers, and plasma lipids in patients with surgically resected early breast cancer. Journal of Clinical Oncology 23 5126-5137.

Lu Q, Liu Y, Long BJ, Grigoryev D, Gimbel M \& Brodie A 1999 The effect of combining aromatase inhibitors with antiestrogens on tumor growth in a nude mouse model for breast cancer. Breast Cancer Research and Treatment 57 183-192.

Lubet RA, Gordon GB, Prough RA, Lei XD, You M, Wang Y, Grubbs CJ, Steele VE, Kelloff GJ, Thomas CF et al. 1998 Modulation of methylnitrosourea-induced breast cancer in Sprague Dawley rats by dehydroepiandrosterone: dose-dependent inhibition, effects of limited exposure, effects on peroxisomal enzymes, and lack of effects on levels of Ha-Ras mutations. Cancer Research 58 921-926.

Luo S, Labrie C, Bélanger A \& Labrie F 1997a Effect of dehydroepiandrosterone on bone mass, serum lipids, and dimethylbenz(a)anthracene-induced mammary carcinoma in the rat. Endocrinology 138 3387-3394.

Luo S, Sourla A, Labrie C, Bélanger A \& Labrie F 1997 b Combined effects of dehydroepiandrosterone and EM-800 on bone mass, serum lipids, and the development of dimethylbenz(a)anthracene (DMBA)-induced mammary carcinoma in the rat. Endocrinology 138 4435-4444.

Luo S, Martel C, Gauthier S, Mérand Y, Bélanger A, Labrie C \& Labrie F 1997c Long term inhibitory effects of a novel antiestrogen on the growth of ZR-75-71 and MCF-7 human breast cancer tumors in nude mice. International Journal of Cancer 73 735-739.

Luu-The V, Dufort I, Paquet N, Reimnitz G \& Labrie F 1995 Structural characterization and expression of the human dehydroepiandrosterone sulfotransferase gene. DNA and Cell Biology 14 511-518.
McCormick DL, Rao KV, Johnson WD, Bowman-Gram TA, Steele VE, Lubet RA \& Kellof GJ 1996 Exceptional chemopreventive activity of low-dose dehydroepiandrosterone in the rat mammary gland. Cancer Research 56 1724-1726.

MacEwen EG \& Kurzman ID 1991 Obesity in the dog: role of the adrenal steroid dehydroepiandrosterone (DHEA). Journal of Nutrition 121 S51-S55.

McGuire WL, Carbone PP, Sears ME \& Escher GC 1975 Estrogen receptors in human breast cancer: an overview. In Estrogen Receptors in Human Breast Cancer, pp 1-7. Eds WL McGuire, PP Carbone \& EP Vollmer. New York: Raven Press.

Martel C, Sourla A, Pelletier G, Labrie C, Fournier M, Picard S, Li S, Stojanovic M \& Labrie F 1998 Predominant androgenic component in the stimulatory effect of dehydroepiandrosterone on bone mineral density in the rat. Journal of Endocrinology 157 433-442.

Martel C, Picard S, Richard V, Bélanger A, Labrie C \& Labrie F 2000 Prevention of bone loss by EM-800 and raloxifene in the ovariectomized rat. Journal of Steroid Biochemistry and Molecular Biology 74 45-56.

Migeon CJ, Keller AR, Lawrence B \& Shepart II TH 1957 Dehydroepiandrosterone and androsterone levels in human plasma. Effect of age and sex: day-to-day and diurnal variations. Journal of Clinical Endocrinology and Metabolism 17 1051-1062.

Miller WR, Telford J, Dixon JM \& Hawkins RA 1985 Androgen receptor activity in human breast cancer and its relationship with estrogen and progesterone receptor activity. European Journal of Cancer and Clinical Oncology 21 539-542.

Morales AJ, Nolan JJ, Nelson JC \& Yen SS 1994 Effects of replacement dose of dehydroepiandrosterone in men and women of advancing age. Journal of Clinical Endocrinology and Metabolism 78 1360-1367.

Mouridsen H, Gershanovich M, Sun Y, Perez-Carrion R, Boni C, Monnier A, Apffelstaedt J, Smith R, Sleeboom HP, Janicke F et al. 2001 Superior efficacy of letrozole versus tamoxifen as first-line therapy for postmenopausal women with advanced breast cancer: results of a phase III study of the international letrozole breast cancer group. Journal of Clinical Oncology 19 2596-2606.

Mouridsen H, Gershanovich M, Sun Y, Perez-Carrion R, Boni C, Monnier A, Apffelstaed J, Smith R, Sleeboom HP, Jaenicke F et al. 2003 Phase III study of letrozole versus tamoxifen as first-line therapy of advanced breast cancer in postmenopausal women: analysis of survival and update of efficacy from the International Letrozole Breast Cancer Group. Journal of Clinical Oncology 21 2101-2109.

Nabholtz JM, Buzdar A, Pollak M, Harwin W, Burton G, Mangalik A, Steinberg M, Webster A \& von Euler M 2000 Anastrozole is superior to tamoxifen as first-line therapy for advanced breast cancer in postmenopausal women: results of a North American multicenter randomized trial. Arimidez Study Group. Journal of Clinical Oncology 18 3758-3767. 
Nestler JE, Barlascini CO, Clore JN \& Blackard WG 1988 Dehydroepiandrosterone reduces serum low density lipoprotein levels and body fat but does not alter insulin sensitivity in normal men. Journal of Clinical Endocrinology and Metabolism 66 57-61.

Orentreich N, Brind JL, Rizer RL \& Vogelman JH 1984 Age changes and sex differences in serum dehydroepiandrosterone sulfate concentrations throughout adulthood. Journal of Clinical Endocrinology and Metabolism 59 551-555.

Osborne CK, Coronado Heinsohn EB, Hilsenbeck SG, McCue BL, Wakeling AE, McClelland RA, Manning DL \& Nicholson RI 1995 Comparison of the effects of a pure steroidal antiestrogen with those of tamoxifen in a model of human breast cancer. Journal of the National Cancer Institute 87 746-750.

Osborne CK, Pippen J, Jones SE, Parker LM, Ellis M, Come S, Gertler SZ, May JT, Burton G, Dimery A et al. 2002 Double-blind, randomized trial comparing the efficacy and tolerability of Fulvestrant versus anastrozole in postmenopausal women with advanced breast cancer progressing on prior endocrine therapy: results of a North American trial. Journal of Clinical Oncology 20 3386-3395.

Paridaens R, Dirix L, Lohrisch C, Beex L, Nooij M, Cameron D, Biganzoli L, Cufer T, Duchateau L, Hamilton A et al. 2003 Mature results of a randomized phase II multicenter study of exemestane versus tamoxifen as first-line hormone therapy for postmenopausal women with metastatic breast cancer. Annals of Oncology 14 1391-1398.

Park JJ, Irvine RA, Buchanan G, Koh SS, Park JM, Tilley WD, Stallcup MR, Press MF \& Coetzee GA 2000 Breast cancer susceptibility gene 1 (BRCAI) is a coactivator of the androgen receptor. Cancer Research 60 5946-5949.

Peto R 1996 Five years of tamoxifen - or more? Journal of the National Cancer Institute 88 1791-1793.

Peto R \& Dalesio O 2003 Breast and prostate cancer: 10 -year survival gains in the hormonal adjuvant treatment trials. ECCO 12, S101. Copenhagen.

Picard F, Deshaies Y, Lalonde J, Samson P, Labrie C, Bélanger A, Labrie F \& Richard D 2000 Effects of the estrogen antagonist EM-652.HCl on energy balance and lipid metabolism in ovariectomized rats. International Journal of Obesity and Related Metabolic Disorders 24 830-840.

Poortman J, Thijssen JH, von Landeghem AA, Wiegerinck MA \& Alsbach GP 1983 Subcellular distribution of androgens and oestrogens in target tissue. Journal of Steroid Biochemistry 19 939-945.

Poulin R \& Labrie F 1986 Stimulation of cell proliferation and estrogenic response by adrenal C19- $\Delta^{5}$-steroids in the ZR-75-71 human breast cancer cell line. Cancer Research 46 4933-4937.

Poulin R, Baker D \& Labrie F 1988 Androgens inhibit basal and estrogen-induced cell proliferation in the ZR-75-71 human breast cancer cell line. Breast Cancer Research and Treatment 12 213-225.
Poulin R, Baker D, Poirier D \& Labrie F 1989a Androgen and glucocorticoid receptor-mediated inhibition of cell proliferation by medroxyprogesterone acetate in ZR-75-71 human breast cancer cells. Breast Cancer Research and Treatment 13 161-172.

Poulin R, Simard J, Labrie C, Petitclerc L, Dumont M, Lagacé L \& Labrie F 1989 b Down-regulation of estrogen receptors by androgens in the ZR-75-71 human breast cancer cell line. Endocrinology 125 392-399.

Powles TJ, Hardy JR, Ashley SE, Farrington GM, Cosgrove D, Davey JB, Dowsett M, McKinna JA, Nash AG, Sinnett HD et al. 1989 A pilot trial to evaluate the acute toxicity and feasibility of tamoxifen for prevention of breast cancer. British Journal of Cancer $60126-131$.

Prostate Cancer Triallists' Collaborative Group 2000 Maximum androgen blockade in advanced prostate cancer: an overview of the randomised trials. Lancet 355 1491-1498.

Rasmussen KR, Arrowood MJ \& Healey MC 1992 Effectiveness of dehydroepiandrosterone in reduction of cryptosporidial activity in immunosuppressed rats. Antimicrobial Agents and Chemotherapy 36 220-222.

Ratko TA, Detrisac CJ, Mehta RG, Kelloff GJ \& Moon RC 1991 Inhibition of rat mammary gland chemical carcinogenesis by dietary dehydroepiandorsterone or a fluorinated analogue of dehydroepiandrosterone. Cancer Research 51 481-486.

Riman T, Dickman PW, Nilsson S, Correia N, Nordlinder H, Magnusson CM, Weiderpass E \& Persson IR 2002 Hormone replacement therapy and the risk of invasive epithelial ovarian cancer in Swedish women. Journal of the National Cancer Institute 94 497-504.

Rodriguez C, Patel AV, Calle EE, Jacob EJ \& Thun MJ 2002 Estrogen replacement therapy and ovarian cancer mortality in a large prospective study of US women. Journal of the American Medical Association 285 1460-1465.

Roy R, Dauvois S, Labrie F \& Bélanger A 1992 Estrogenstimulated glucuronidation of dihydrotestosterone in MCF-7 human breast cancer cells. Journal of Steroid Biochemistry and Molecular Biology 41 579-582.

Sabnis GJ, Jelovac D, Long B \& Brodie A 2005 The role of growth factor receptor pathways in human breast cancer cells adapted to long-term estrogen deprivation. Cancer Research 65 3903-3910.

Sato M, Turner CH, Wang T, Adrian MD, Rowley E \& Bryant HU 1998 LY353381.HCl: a novel raloxifene analog with improved SERM potency and efficacy in vivo. Journal of Pharmacological and Experimental Therapy 287 1-7.

Schiff R, Massarweh SA, Shou J, Bharwani L, Arpino G, Rimawi M \& Osborne CK 2005 Advanced concepts in estrogen receptor biology and breast cancer endocrine resistance: implicated role of growth factor signaling and estrogen receptor coregulators. Cancer Chemotherapy and Pharmacology 56 (Suppl 1) 10-20. 
Schriock ED, Buffington CK, Hubert GD, Kurtz BR, Kitabchi AE, Buster JE \& Givens JR 1988 Divergent correlations of circulating dehydroepiandrosterone sulfate and testosterone with insulin levels and insulin receptor binding. Journal of Clinical Endocrinology and Metabolism 66 1329-1331.

Schwartz AG, Pashko L \& Whitcomb JM 1986 Inhibition of tumor development by dehydroepiandrosterone and related steroids. Toxicology and Pathology 14 357-362.

Segaloff A 1977 The use of androgens in the treatment of neoplastic disease. Pharmacological Therapy C2 33-37.

Segaloff A, Gordon D, Horwitt BN, Schlosser JV \& Murison PJ 1951 Hormonal therapy in cancer of the breast. 1. The effect of testosterone propionate therapy on clinical course and hormonal excretion. Cancer 4 319-323.

Sherwin BB 2003 Estrogen and cognitive functioning in women. Endocrine Reviews 24 133-151.

Shilkaitis A, Green A, Punj V, Steele VE, Lubet RA \& Christov K 2005 Dehydroepiandrosterone inhibits the progression phase of mammary carcinogenesis by inducing cellular senescence via a p16-dependent but p53-independent mechanism. Breast Cancer Research and Treatment 7 R1132-R1138.

Simard J, Vincent A, Duchesne R \& Labrie F 1988 Full oestrogenic activity of $\mathrm{C}_{19}-\Delta^{5}$-adrenal steroids in rat pituitary lactotrophs and somatotrophs. Molecular and Cellular Endocrinology 55 233-242.

Simard J, Hatton AC, Labrie C, Dauvois S, Zhao HF, Haagensen DE \& Labrie F 1989 Inhibitory effects of estrogens on GCDFP-15 mRNA levels and secretion in ZR-75-71 human breast cancer cells. Molecular Endocrinology 3 694-702.

Simard J, Dauvois S, Haagensen DE, Lévesque C, Mérand Y \& Labrie F 1990 Regulation of progesterone-binding breast cyst protein GCDFP-24 secretion by estrogens and androgens in human breast cancer cells: a new marker of steroid action in breast cancer. Endocrinology 126 3223-3231.

Simard J, Labrie C, Bélanger A, Gauthier S, Singh SM, Mérand Y \& Labrie F $1997 a$ Characterization of the effects of the novel non-steroidal antiestrogen EM-800 on basal and estrogen-induced proliferation of T-47D, ZR-75-71 and MCF-7 human breast cancer cells in vitro. International Journal of Cancer 73 104-112.

Simard J, Sanchez R, Poirier D, Gauthier S, Singh SM, Mérand Y, Bélanger A, Labrie C \& Labrie F $1997 b$ Blockade of the stimulatory effect of estrogens, $\mathrm{OH}$-tamoxifen, $\mathrm{OH}$-toremifene, droloxifene and raloxifene on alkaline phosphatase activity by the antiestrogen EM-800 in human endometrial adenocarcinoma Ishikawa cells. Cancer Research $\mathbf{5 7}$ 3494-3497.

Simoncini T, Fornari L, Mannella P, Varone G, Caruso A, Liao JK \& Genazzani AR 2002 Novel nontranscriptional mechanisms for estrogen receptor signaling in the cardiovascular system. Interaction of estrogen receptor alpha with phosphatidylinositol 3-OH kinase. Steroids 67 935-939.

Simpson ER 2000 Role of aromatase in sex steroid action. Journal of Molecular Endocrinology 25 149-156.

Sourla A, Martel C, Labrie C \& Labrie F 1998 Almost exclusive androgenic action of dehydroepiandrosterone in the rat mammary gland. Endocrinology 139 753-764.

Stomati M, Monteleone P, Casarosa E, Quirici B, Puccetti S, Bernardi F, Genazzani AD, Rovati L, Luisi M \& Genazzani AR 2000 Six-months oral dehydroepiandrosterone supplementation in early and late postmenopause. Gynecological Endocrinology 14 342-363.

Suzuki T, Suzuki N, Daynes RA \& Engleman EG 1991 Dehydroepiandrosterone enhances IL2 production and cytotoxic effector function of human T cells. Clinical Immunology and Immunopathology 61 202-211.

Szymczak J, Milewicz A, Thijssen JH, Blankenstein MA \& Daroszewski J 1998 Concentration of sex steroids in adipose tissue after menopause. Steroids 63 319-321.

Tchernof A, Després JP, Bélanger A, Dupont A, Prud'homme D, Moorjani S, Lupien PJ \& Labrie F $1995 a$ Reduced testosterone and adrenal C19 steroid levels in obese men. Metabolism 44 513-519.

Tchernof A, Després JP, Dupont A, Bélanger A, Nadeau A, Prud'homme D, Moorjani S, Lupien PJ \& Labrie F $1995 b$ Relation of steroid hormones to glucose tolerance and plasma insulin levels in men. Diabetes Care $\mathbf{1 8}$ 292-299.

Tormey DC, Lippman ME, Edwards BK \& Cassidy JG 1983 Evaluation of tamoxifen doses with and without fluoxymesterone in advanced breast cancer. Annals of Internal Medicine 98 139-144.

Tralongo P, Di Mari A \& Ferrau F 2005 Cognitive impairment, aromatase inhibitors, and age. Journal of Clinical Oncology 234243.

Trams G \& Maass H 1977 Specific binding of estradiol and dihydrotestosterone in human mammary cancers. Cancer Research 37 258-261.

Ulrich P 1939 Testosterone (hormone mâle) et son role possible dans le traitement de certains cancers du sein. Acta - Unio Internationalis Contra Cancrum 377-379.

Vermeulen A \& Verdonck L 1976 Radioimmunoassays of $17 \beta$-hydroxy-5 $\alpha$-androstan-3-one, 4-androstene-3,17dione, dehydroepiandrosterone, $17 \beta$-hydroxyprogesterone and progesterone and its application to human male plasma. Journal of Steroid Biochemistry 7 1-10.

Vermeulen A, Deslypene JP, Schelfhout W, Verdonck L \& Rubens R 1982 Adrenocortical function in old age: response to acute adrenocorticotropin stimulation. Journal of Clinical Endocrinology and Metabolism 54 187-191.

Wakeling AE \& Bowler J 1988 Biology and mode of action of pure antiestrogens. Journal of Steroid Biochemistry 30 141-147.

Watson AA, Huls R, Araghinikuam M \& Chung S 1996 Dehydroepiandrosterone and diseases of aging. Drugs Aging 9 274-291. 
Weiss NS, Ure CL, Ballard JH, Williams AR \& Daling JR 1980 Decreased risk of fractures of the hip and lower forearm with postmenopausal use of estrogen. New England Journal of Medicine 303 1195-1198.

Women's Health Initiative 2002 Risks and benefits of estrogen plus progestin in healthy postmenopausal women. Journal of the American Medical Association 288 321-333.

Wooster R, Mangion J, Eeles R, Smith S, Dowsett M, Averill D, Barrett-Lee P, Easton DF, Ponder BA \& Stratton MR 1992 A germline mutation in the androgen receptor in two brothers with breast cancer and Reifenstein syndrome. Nature Genetics 2 132-134.
Yaffe K 1998 Estrogen therapy in postmenopausal women: effects on cognitive function and dementia. Journal of the American Medical Association 279 688-695.

Zhou J, Ng S, Adesanya-Famuiya O, Anderson K \& Bondy CA 2000 Testosterone inhibits estrogen-induced mammary epithelial proliferation and suppresses estrogen receptor expression. FASEB Journal 14 $1725-1730$.

Zumoff B, Levin J, Rosenfeld RS, Markham M, Strain GW \& Fukushima DK 1981 Abnormal 24-hr mean plasma concentrations of dehydroepiandrosterone and dehydroisoandrosterone sulfate in women with primary operable breast cancer. Cancer Research 41 3360-3363. 
